\title{
辽东半岛早白严世伸展构造组合、形成时代及区域 构造内涵
}

\author{
刘俊来 ${ }^{(1 *}$ ，纪沫 ${ }^{(1)}$ ，申亮 ${ }^{(1)}$ ，关会梅 ${ }^{(2)}$, Gregory A DAVIS ${ }^{(4)}$ \\ (1) 中国地质大学地质过程与矿产资源国家重点实验室, 北京 100083 ; \\ (2) 中国海洋石油总公司研究总院, 北京 100027; \\ (3) 中国地质科学院地质力学研究所, 北京 100081; \\ (4) Department of Earth Sciences, University of Southern California, Los Angeles, CA90089-0740, USA \\ *E-mail: jliu@cugb.edu.cn
}

收稿日期: 2010-07-25; 接受日期: 2010-12-17

国家自然科学基金重大研究计划(批准号: 90814006)和教育部“111”计划(编号: B07011)资助

\begin{abstract}
摘要辽东半岛地区广泛发育了多种不同类型的伸展构造, 包括伸展断陷盆地(通远堡、 本溪和丹东)、拆离断层(大营子)和变质核杂岩(辽南和万福), 它们具有宏观一致性但却表现 出一定的差异. 西部地区, 结伴发育了两个共用同一下盘的变质核杂岩一一辽南和万福变 质核杂岩; 中东部地区发育了大营子拆离断层系; 东部地区广泛发育了多个伸展断陷盆地. 对于伸展构造相关的同构造侵入岩与伸展断陷盆地火山岩的年代学分析揭示出伸展构造总 体发育于 135 106 Ma 之间, 但是各个伸展构造发育时间有一定的差异. 伸展构造具有运动 学统一性、几何学上的不对称性和构造-岩浆共同活动性; 它们在形成时间上具有差异性与 跨越性, 区域产状变化与切割深度的不一致性; 伸展构造宏观上构成共轭组合, 但单个伸展 构造却具有不对称性. 华北、东北、华南乃至蒙古和俄罗斯远东地区的早白严世伸展构造与 辽东半岛地区伸展构造的发育具有统一的组合规律, 可以认为辽东半岛地区伸展构造的发 育是东亚早白严世伸展构造域的缩影. Izanagi 板块与欧亚板块之间的交互作用以及东亚地 区岩石圈结构调整、深部流体活动性和壳幔拆离作用是制约东亚地区早白严世伸展构造发 育的重要因素.
\end{abstract}

关键词

辽东半岛

白严纪伸展作用

形成时代

东亚

华北克拉通
作为华北克拉通的一部分, 辽东半岛地区的演化 与之具有共性, 但也具有特殊性. 自古元古代末期克 拉通化后该区经历了稳定陆内发展阶段, 一直到中奥 陶世仅仅在瓦房店地区发育了含有金刚石的金伯利 岩 ${ }^{[1]}$. 印支期开始, 扬子板块与华北板块的碰撞及碰撞 后的伸展作用影响到这一地区. 与此同时, 伴随发育了
局部的花岗质岩浆侵位和盖层地层的褶皱 ${ }^{[2]}$. 侏罗纪以 来该区又受到强烈的构造-岩浆活动性的改造, 在白严 纪时期达到鼎盛阶段. 该阶段的构造-岩浆活动性, 是 华北克拉通显生宙破坏的结果和具体表现(图 1(a)).

辽东半岛地区是华北克拉通晚中生代岩石圈减 薄最为强烈和典型的地区. 尤其是在早白严世，伸展

英文引用格式: Liu J L, Ji M, Shen L, et al. Early Cretaceous extensional structures in the Liaodong Peninsula: Structural associations, geochronological constraints and regional tectonic implications. Sci China Earth Sci, 2011, 54: 823-842, doi: 10.1007/s11430-011-4189-y 
作用异常强烈, 最直接的表现就是辽南变质核杂岩 构造的发育. 在此基础上, 在约 $40000 \mathrm{~km}^{2}$ 范围内我 们新近发现和厘定了数个新变质核杂岩构造(包括万 福和达子营变质核杂岩构造)、许多拆离断层构造(如 大营子拆离断层系) 以及断陷盆地(如通远堡和丹东 盆地), 它们的存在为阐明早白严世华北克拉通地壳 的伸展与减薄提供了契机(图 1). 从伸展构造的组成、 结构、产状、运动学方式和动力学特点等各个方面来 看, 辽东半岛地区的这些伸展构造与华北克拉通区 其他部位发育的变质核杂岩构造具有统一性 ${ }^{[3,4]}$. 依 据华北克拉通破坏与岩石圈减薄的浅部构造表现, 可以认为辽东半岛地区是华北克拉通晚中生代区域 构造演化的缩影.

\section{1 早白严世伸展构造}

广义的伸展构造包括拆离断层带、变质核杂岩、 断陷盆地、地堑和地垒、裂谷以及岩墙群 ${ }^{[5]}$. 它们具 有不同的表现, 并反映了不同的伸展作用特点. 在辽 东半岛地区发育的伸展构造主要包括了拆离断层 (带)、变质核杂岩和断陷盆地(图 1(b)). 拆离断层带属 于低角度正断层构造, 往往具有大于 $10 \mathrm{~km}$ 的位移. 其巨大的位移常常将中部地壳岩石位移到地表, 并 构成变质核杂岩构造. 作为区域伸展构造的重要表 现型式, 变质核杂岩构造是由拆离断层带、上盘弱变 形、未变质的沉积岩组合和下盘变质程度可以达到角 闪岩相的变质岩石组合构成的一组构造. 拆离断层 带由位于顶部的主拆离断层面和其下伏可达数公里 厚的糜棱岩带构成, 上盘往往有铲状正断层组合、多 米诺构造及上叠盆地, 而下盘经常有同构造就位的 侵入岩体侵入于变质岩中. 由铲状断层控制的半地 堑盆既可以独立出现, 也可以在变质核杂岩主拆离 断层的上盘形成. 它们往往成组出现, 边界断层单向 倾斜, 并构成断陷盆地群.

\section{1 辽南-万福变质核杂岩对}

辽东半岛南部地区，结伴发育了两个共用同一 下盘的变质核杂岩构造(图 1(b)), 即辽南变质核杂 岩 ${ }^{[6]}$ 和万福变质核杂岩 ${ }^{[7]}$. 位于西侧的辽南变质核杂 岩具有 3 层结构, 由 5 部分构成, 包括上盘原地岩块 与其断陷形成的半地堑状上叠盆地、下盘太古宙深成 变质杂岩与同构造侵入岩体和介于上下盘之间的主 拆离断层带 ${ }^{[6]}$. 上盘岩块主要为新元古代与古生代弱
变形沉积岩系, 并且经历过印支期变形作用的强烈 改造, 发育近东西向展布的褶皱-逆冲断层系. 瓦房 店-普兰店上叠盆地中发育了早白严世火山-沉积岩 系. 下盘变质杂岩以太古宙 TTG 片麻岩系为主, 并 有少量变质表壳岩系, 它们被侏罗纪花岗岩和早白 普世同构造二长花岗岩-花岗岩杂岩(饮马湾山复式 杂岩)侵入. 分隔上下盘的主拆离断层带由两个分支 构成, 即西侧 NNE 向的金州拆离断层(倾向西)和东 南侧的董家沟拆离断层(倾向南). 其中金州主拆离断 层面平面具有典型的波瓦状构造格局，而且波瓦构 造背形部位常常伴随着较晚期阶段同构造就位岩体 的发育, 也从一个侧面说明岩体的同构造属性. 主拆 离断层面下伏记录地壳不同层次拆离作用历史的各 种不同类型的构造岩, 由拆离断层面向下依次出现 微角砾岩、假玄武玻璃、角砾岩化糜棱岩、糜棱岩、 糜棱岩化片麻岩和片麻岩, 揭示出下盘岩石从中部 地壳逐渐剥露的完整过程. 构造测量资料表明, 无论 是拆离带和下盘岩石, 还是侵入下盘的同构造花岗 岩中, 都普遍发育一组具有统一方向性特征的拉伸 线理构造, 且与主拆离断层面上的擦痕构造及波瓦 状构造的枢纽方向一致 $\left(\mathrm{SE} 130^{\circ} \sim \mathrm{NW} 310^{\circ}\right)$, 显示出相 同的运动学方式(下盘向 SEE 方向运动).

万福核杂岩同样具有典型的三层结构 ${ }^{[7]}$. 下盘主 要由大面积出露的晚中生代花岗岩侵入体(包括北部 古道岭花岗岩和庙岭石英闪长岩, 南部与辽南变质 核杂岩共用的饮马湾山二长花岗岩-花岗岩杂岩)构 成, 局部(南部)出现太古宙片麻岩, 即得胜、亮甲店 和姚岭片麻岩. 主拆离断层面总体走向近南北, 倾向 东, 倾角为 $20^{\circ} \sim 30^{\circ}$, 下伏拆离断层带由主拆离断层 面及其下部的碎裂岩和糜棱状岩石构成，表现为不 同阶段递进演化的断层构造岩组合, 其中较新的脆 性拆离断层面位于主拆离断层带的顶部, 下伏为拆 离断层带较深层次演化形成的碎裂岩带和糜棱岩带. 出露的碎裂岩带平均厚度约为 $50 \mathrm{~m}$, 糜棱岩带的厚 度较大, 局部超过 $8 \mathrm{~km}$. 上盘地层由元古宇辽河群 和永宁群组成, 其中万福镇南部主要为永宁群钻质 石英砂岩、含砾长石石英砂岩夹砾岩及板岩组合; 万 福镇以北地区为辽河群片岩、千枚岩、板岩为主夹石 英砂岩和结晶灰岩组合及少量出露的长石石英砂岩、 变质含砾长石石英砂岩、变质石英砂岩及变质粉砂岩 夹少量变质泥质岩石. 在拆离断层上盘的桂云花火 山-沉积盆地总面积约 $50 \mathrm{~km}^{2}$, 沉积下白严统桂云花 组安山岩-流纹岩及层状砂砾沉积岩组合.

万福与辽南变质核杂岩相伴发育(图 2), 主拆离 


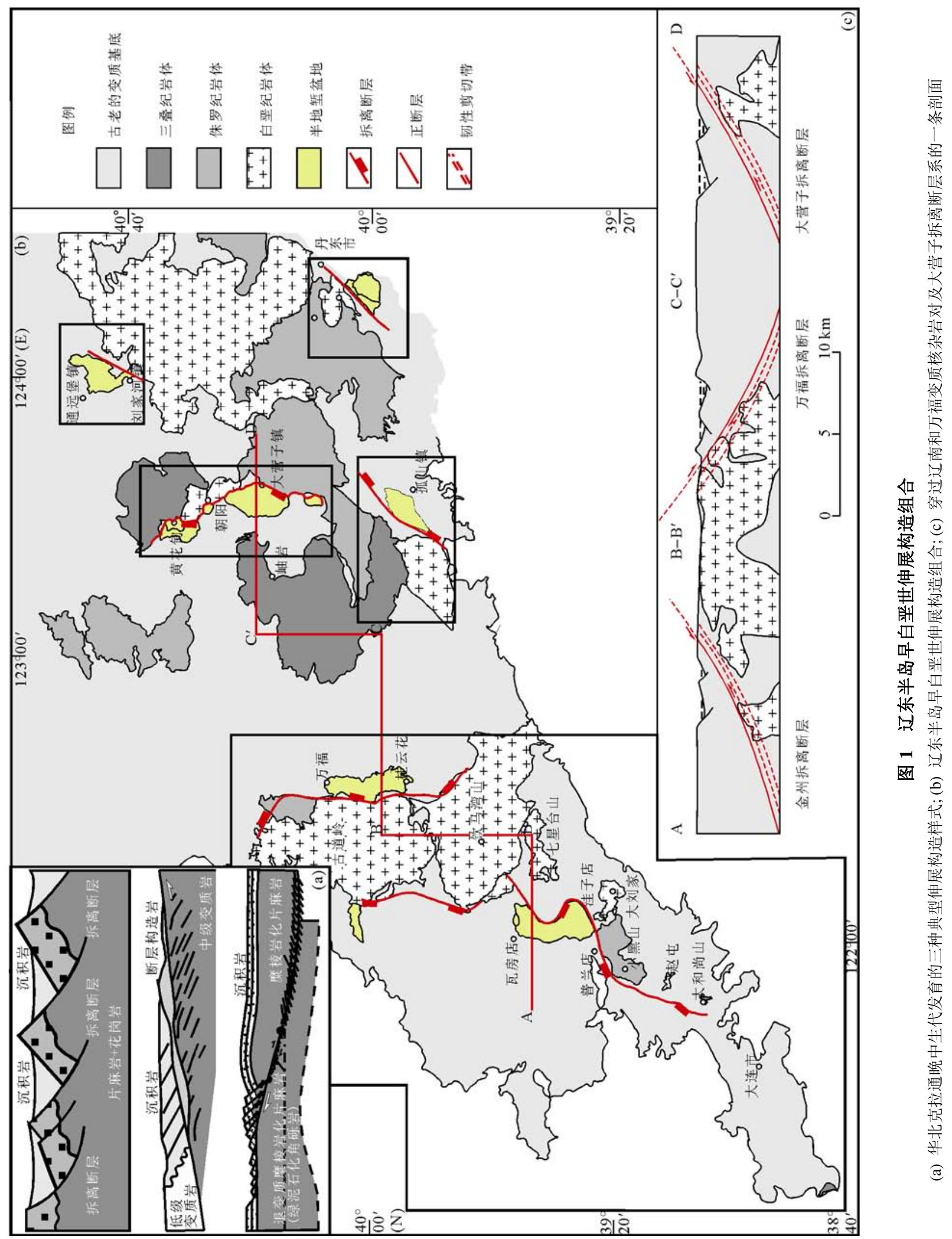



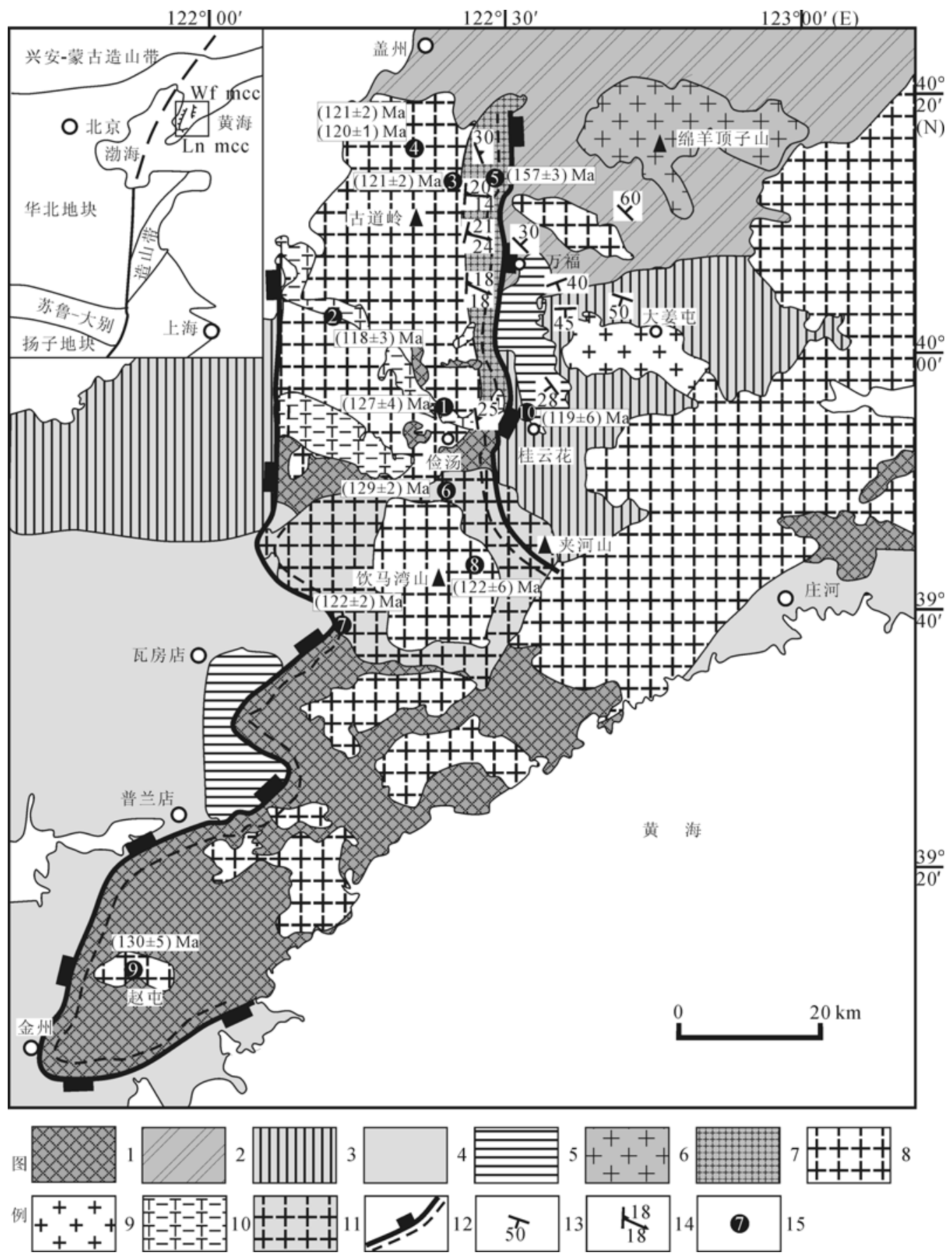

图 2 辽南-万福变质核杂岩构造地质图 ${ }^{[7]}$

1 , 太古宇变质岩; 2 , 古元古代辽河群盖县组; 3 , 新元古代永宁组; 4 , 古生界; 5 , 白严纪火山-沉积地层; 6 , 古元古代花岗岩; 7 , 侏罗纪侵入 岩体; 8 , 白严纪同构造侵入岩体; 9 , 大姜屯岩体; 10 , 庙岭岩体; 11 , 双塔杂岩; 12 , 主拆离断层及糜棱岩带; 13 , 地层产状; 14 , 岩体叶理及线 理产状; 15 , 同位素年龄采样点及编号; 图中点 $1 \sim 3,5,6$ 和 9 数据引自吴福元等 ${ }^{[8]}$, 点 4 数据引自 $\mathrm{Wu}$ 等 ${ }^{[9]}$, 数据 7 和 8 引自郭春丽等 ${ }^{[10]}$, 点

10 数据引自辽宁省地质调查院 ${ }^{1)}$. 左上角插图为华北东部地区构造纲要图, 其中, Wf mcc 是万福变质核杂岩, Ln mcc 是辽南变质核杂岩

1) 辽宁省地质调查院. 桂云花等五幅 $1: 5$ 万区调联测报告. 2001 
断层倾向相反, 但共用同一个下盘变质杂岩单元. 小 规模白严纪上叠盆地局部发育. 从上盘运动学特点 考虑, 金州与万福拆离断层延伸同为南北向, 运动学 指向标志揭示出金州拆离断层下盘向 SEE 运动，而 万福拆离断层下盘向 $\mathrm{NWW}$ 向运动, 二者运动方向对 峙, 构成变质核杂岩对(图 1(c) $)^{[7]}$.

对于变质核杂岩对各个组成单元开展的构造分 析与测年资料综合分析揭示出, 变质核杂岩的形成 始于地壳的区域性伸展, 伸展作用诱发了花岗岩岩 浆的形成与就位，而结束于假玄武玻璃和断层泥等 构造岩的形成. 下盘花岗岩的单颗粒锆石 U-Pb 年龄 约为 $130 \mathrm{Ma}$, 而切过金州主拆离断层带的花岗斑岩 体锆石 $\mathrm{U}-\mathrm{Pb}$ 年龄约为 $113 \mathrm{Ma}^{[11]}$.

\section{2 大营子拆离断层系}

大营子拆离断层系位于辽东半岛东南部, 主要 由大营子-黄花甸拆离断层带、下盘古元古代变质岩 系和侵入岩体, 以及上盘火山-沉积盆地三部分组 成 ${ }^{[12]}$ (图 3). 上盘火山沉积盆地主要分布在大营子和 黄花甸两地, 由一套白严纪中酸性火山岩 (以安山岩 为主夹少量流纹岩)及砂砾岩组成. 下盘古元古代变 质岩系属于辽河群, 为一套层状中浅变质岩系, 主要 由下部的二长浅粒岩、变粒岩、黑云变粒岩及阳起透 闪变粒岩、白云石大理岩夹黑云微斜片麻岩及斜长浅 粒岩等, 中部的方解大理岩、黑云斜长变粒岩和上部 的二云片岩组成. 同时, 该套岩系被中生代 (三叠纪 花岗岩(224 \pm 1$)$ 和 $(226 \pm 1) M a$ 、侏罗纪黑云二长花岗岩 $(155 \pm 1) \mathrm{Ma}$ 和白垩纪二长岩 $(127 \pm 1)$ 和 $(128 \pm 1)$ $\mathrm{Ma})^{[8,12]}$ 岩体侵位. 分隔上下盘的拆离断层主要展布 于大营子和黄花甸一线, 走向自南向北由 NNE 向逐

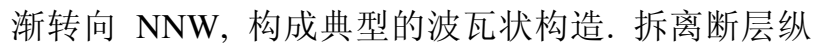
贯南北延伸约 $70 \mathrm{~km}$, 切过了古元古代变质岩系, 并 控制了大营子和黄花甸盆地早白垩世火山岩系的发 育. 拆离断层带自下而上由片麻状黑云二长花岗岩、 花岗质糜棱岩、碎裂糜棱岩、微角砾岩及断层泥组成, 其显微构造和石英 EBSD 组构分析揭示出下盘岩石 主要经历了从高绿片岩相到低绿片岩相的变形变质 过程 ${ }^{[12]}$. 普遍发育的拉伸线理与断层面上发育的擦 痕构造具有运动学上的一致性, 均指示近 E-W 向拉 伸, 并显示出相同的运动方式, 即下盘向 SEE 方向运 动.

三叠纪和侏罗纪岩体属于构造前岩体, 岩体边
部遭受拆离断层作用改造, 而白严纪岩体则属构造 后侵位岩体, 岩体保留原岩特点, 未遭受剪切变形作 用改造. 它们的存在对于拆离断层作用的活动年龄 给予了初步的约束, 而对于拆离断层上叠盆地火山 岩的年代学分析揭示出, 在黄花甸盆地内底部流纹 岩锆石 $\mathrm{U}-\mathrm{Pb}$ 年龄为 $(135 \pm 1) \mathrm{Ma}$ ，大营子盆地内部安 山岩锆石 $\mathrm{U}-\mathrm{Pb}$ 年龄为 $(132 \pm 5) \mathrm{Ma}^{[12]}$. 由此我们可以 限定出拆离断层作用的年龄为 $135 \sim 127 \mathrm{Ma}$, 无论是 起始年龄还是结束活动年龄都大于辽南和万福变质 核杂岩主拆离断层带.

\section{3 断陷盆地}

辽东半岛地区发育的断陷盆地构造主要包括通 远堡、本溪和丹东盆地(图 4). 其中, 通远堡盆地受其 东南缘断层控制(图 4(a)), 古元古界辽河群里尔峪组 含磁铁电气石变粒岩、黑云变粒岩、钻硅酸盐岩和大 理岩, 高家峪组片岩、变粒岩、含墨透辉透闪变粒岩 夹斜长角闪岩、大理岩和透闪石岩, 王家沟组条带状 方解石大理岩夹白云石大理岩, 华子峪组二云片岩、 黑云片岩夹大理岩和透辉透闪变粒岩, 盖县组二云 片岩夹二云变粒岩、含墨透闪透辉变粒岩、变质石英 砂岩及千枚岩出露于断层上下两盘. 下盘广泛发育 白严纪千山中粒角闪石钾长花岗岩、中粒黑云母钾长 花岗岩和细粒钾长花岗岩, 丁岐山中粗粒石英正长 岩和中细粒石英二长岩, 铜匠峪中细粒条痕状二长 花岗岩和细粒条痕状斜长花岗岩. 断陷盆地为桂云 花组构成的火山-沉积盆地, 充填一套以中性火山岩 为主的陆相火山-沉积建造, 一段以灰色中细粒复成 分砾岩、黄绿色泥质粉砂岩和中细粒凝灰质砂岩为主 夹粉砂质泥岩和页岩, 以沉积作用为主，伴随较弱的 火山活动; 二段以灰绿色安山岩、灰绿-灰紫色安山质 火山角砾岩、安山质凝灰角砾岩及安山玄武岩为主, 夹有灰绿-灰紫色凝灰质粉砂岩、凝灰质砂岩及细砾 岩等，以脉动式中性火山喷发为主，仅在火山间歇期 出现沉积作用; 三段以灰紫、灰黄色流纹质角砾凝灰 岩、流纹质熔结角砾凝灰岩、流纹质角砾熔岩、流纹 岩及安山质角砾熔岩为主, 夹灰色安山岩和含角砾 岩屑砂岩等, 以脉动式酸性火山喷发为主.

本溪断陷盆地受其南缘正断层控制(图 4(b)), 下 盘出露太古宇鞍山群大峪沟组二云石英片岩、黑云变 粒岩、二云变粒岩及浅粒岩夹磁铁石英岩扁豆体，原 岩为酸性火山-沉积岩建造, 经历绿帘角闪岩相变质 


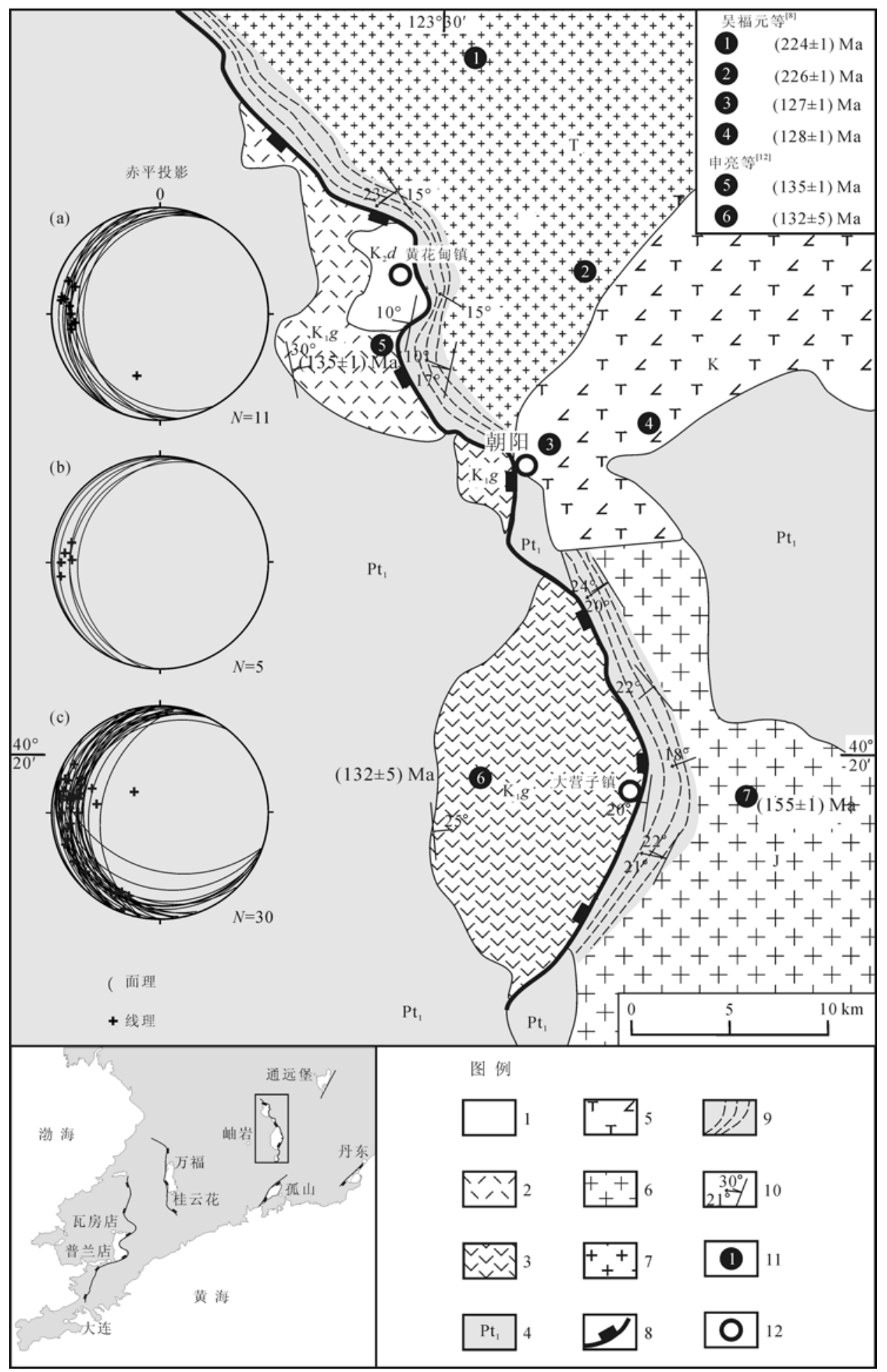

图 3 大营子拆离断层系地质简图 ${ }^{[12]}$

赤平投影图(a)和(c)分别为黄花甸段和大营子段糜棱岩面理(大圆弧)和线理(十字)构造统计(下半球等面积投影); (b)为大营子-黄花甸主拆离 断层面及擦痕构造统计; 左下角插图为辽东半岛伸展构造分布图. 1, 上白严统大峪组沉积岩; 2 , 下白严统桂云花组中酸性火山岩(黄花甸镇); 3, 下白严统桂云花组中性火山岩(大营子镇); 4, 古元古代变质岩系; 5 , 白严纪二长岩; 6 , 侏罗纪花岗岩; 7 , 三叠纪花岗岩; 8 , 主拆离断层; 9 , 拆离断层带; 10, 面理和线理; 11, 前人测年采样点; 12, 城镇 


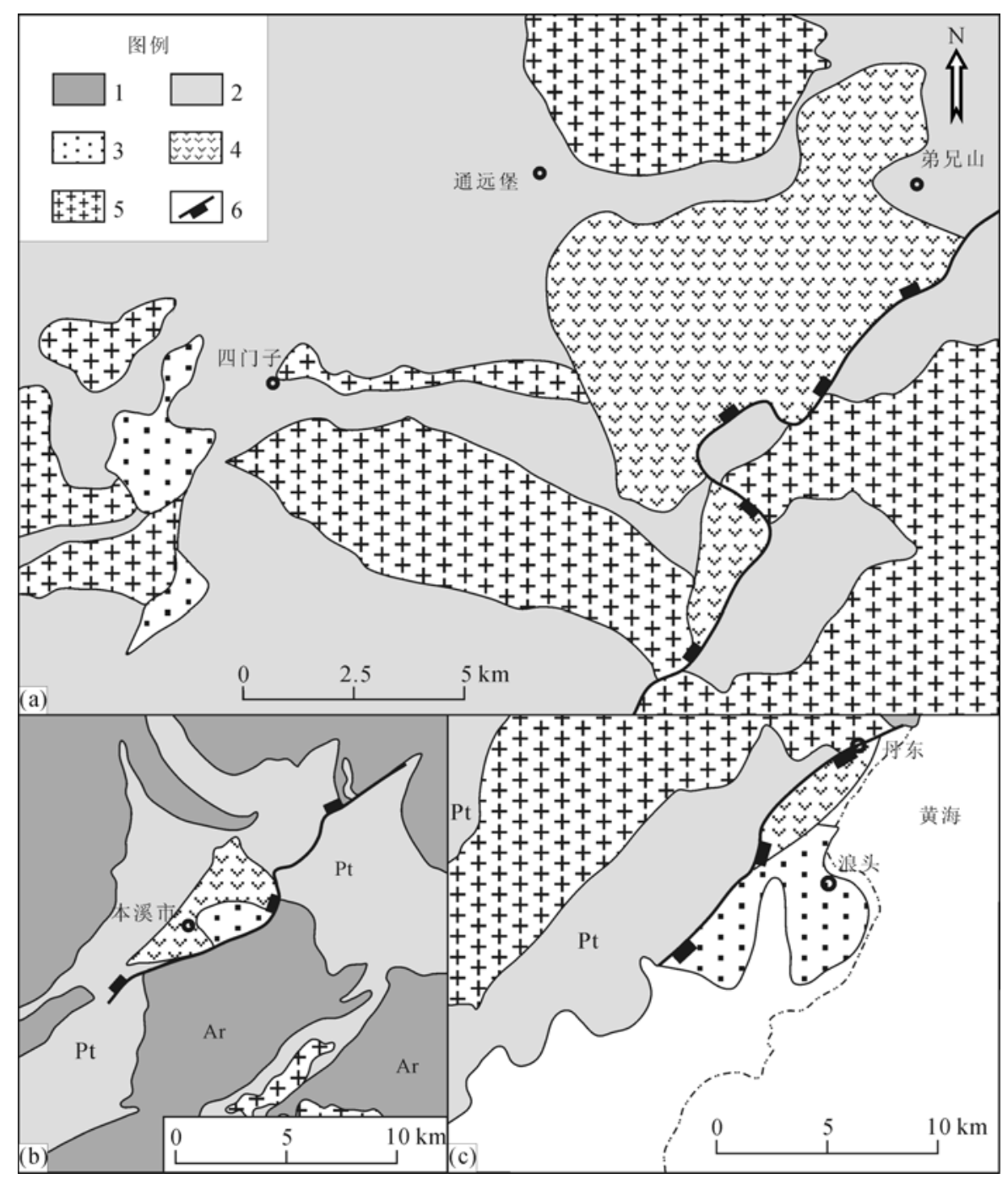

图 4 辽东半岛断陷盆地构造简图

(a) 通远堡盆地; (b) 本溪盆地; (c) 丹东盆地. 1 , 太古宙变质岩; 2 , 元古宙变质岩; 3 , 上白严统大峪组沉积岩; 4 , 下白严统桂云花组火山岩; 5 , 下盘侵入岩体; 6, 正断层

作用; 震旦系南芬组泥灰岩和页岩, 桥头组石英砂岩 夹页岩，康家组泥灰岩、灰岩和页岩.上盘出露奥陶 系灰岩、白云质灰岩、含燧石结核灰岩、结晶白云岩、 泥灰岩，石炭系粉砂岩、页岩、炭质页岩夹铝土矿和 煤，二叠系砂岩和页岩夹煤. 断陷盆地充填小东沟组 灰紫灰绿色页岩、砂岩夹泥灰岩及砾岩, 白严系桂云 花组流纹岩、安山岩夹页岩和大峪组紫色砾岩夹红色 砂岩及灰紫色砂岩.

丹东盆地受盆地西北缘正断层控制(图 4(c)), 下 盘出露古元古界辽河群高家峪组片岩、变粒岩、含墨 透辉透闪变粒岩夹斜长角闪岩、大理岩、透闪岩和盖
县组二云片岩夹变粒岩、变质石英砂岩及千枚岩、二 云片岩夹二云变粒岩和含墨透辉透闪变粒岩; 同时 出露早白严世太平岭单元中细粒似斑状二长花岗岩 和侏罗纪莲花盆单元片麻状中细粒二云母二长花岗 岩. 上盘盆地为白严系沉积地层充填, 桂云花组下部 主要为灰色、黄绿色和灰绿色凝灰岩、安山质凝灰岩、 安山质凝灰熔岩、含砾凝灰质砂岩、凝灰质砂岩夹粉 砂岩和页岩组成, 上部主要为紫色和紫红色凝灰岩、 凝灰质砂岩、凝灰质胶结砾岩、紫色薄层粉砂岩夹紫 色安山岩及泥灰岩. 梨树沟组为灰色铁质胶结岩屑 砂岩、复成分砾岩、沉凝灰岩、粗粒岩屑砂岩和粉砂 
岩等, 沉积环境为河湖相. 大峪组岩性主要为紫色铁 质胶结长石岩屑砂岩、粉砂质泥岩、厚层砾岩和泥晶 灰岩等, 为紫色陆源碎屑河湖相沉积.

\section{2 伸展构造形成的年代学}

辽东半岛地区伸展构造的发育具有宏观意义上 的等时性, 主要发育于 135 106 Ma. 但是不同地区 伸展作用的时间性还是存在着一定的差异. 一方面 拆离断层下盘就位的同构造花岗岩对于变质下盘的 剥露提供了年代学依据, 另一方面伸展断陷盆地或 者上叠盆地的火山活动性为伸展断陷作用的发育时
间提供了重要的约束. 下述将重点描述与辽东半岛 地区伸展构造发育相关的几个典型伸展断陷盆地内 火山岩的年代学测试结果, 以期对于区域伸展作用 提供时间约束.

\section{1 测试样品}

辽东半岛地区广泛分布伸展构造，辽南和万福 变质核杂岩, 大营子拆离断层系, 丹东、通远堡和本 溪断陷盆地，其上盘均发育白严纪上叠盆地，依次定 名为瓦房店-普兰店、桂云花、黄花甸、大营子、丹 东、通远堡和本溪盆地. 本文测年所选取的样品均来 自上述盆地中发育的火山岩, 具体参见表 1 .

表 1 辽东半岛地区伸展构造内岩浆岩测年样品一览表

\begin{tabular}{cccc}
\hline 样品号 & 采样点 & 岩性 & 岩石学特征 \\
\hline SL0585 & 瓦房店-普兰店 & 安山岩 & 灰绿色, 斑状结构, 斜长石和钾长石成斑晶, 斜长石发育聚片双晶, \\
SL05128 & 桂云花 & 共质为交织结构(图 5(a)和(b)) \\
SL0768 & 丹东 & 安山岩 & 灰紫色, 斜长石呈斑晶, 具交织结构(图 6(a)和(b)) \\
SL0734-4 & 通远堡 & 斑晶角闪石暗化, 保留假象呈长柱状(图 7(a)和(b)) \\
SL0719 & 本花岗质脉岩 & 灰白色, 以长石和石英为主, 二者近等粒状, 且石英斑晶具熔蚀和 \\
& 流纹岩 & 紫灰色, 以长石和石英为主, 基质为细晶长石和石英, 可见铁质等 \\
\hline
\end{tabular}
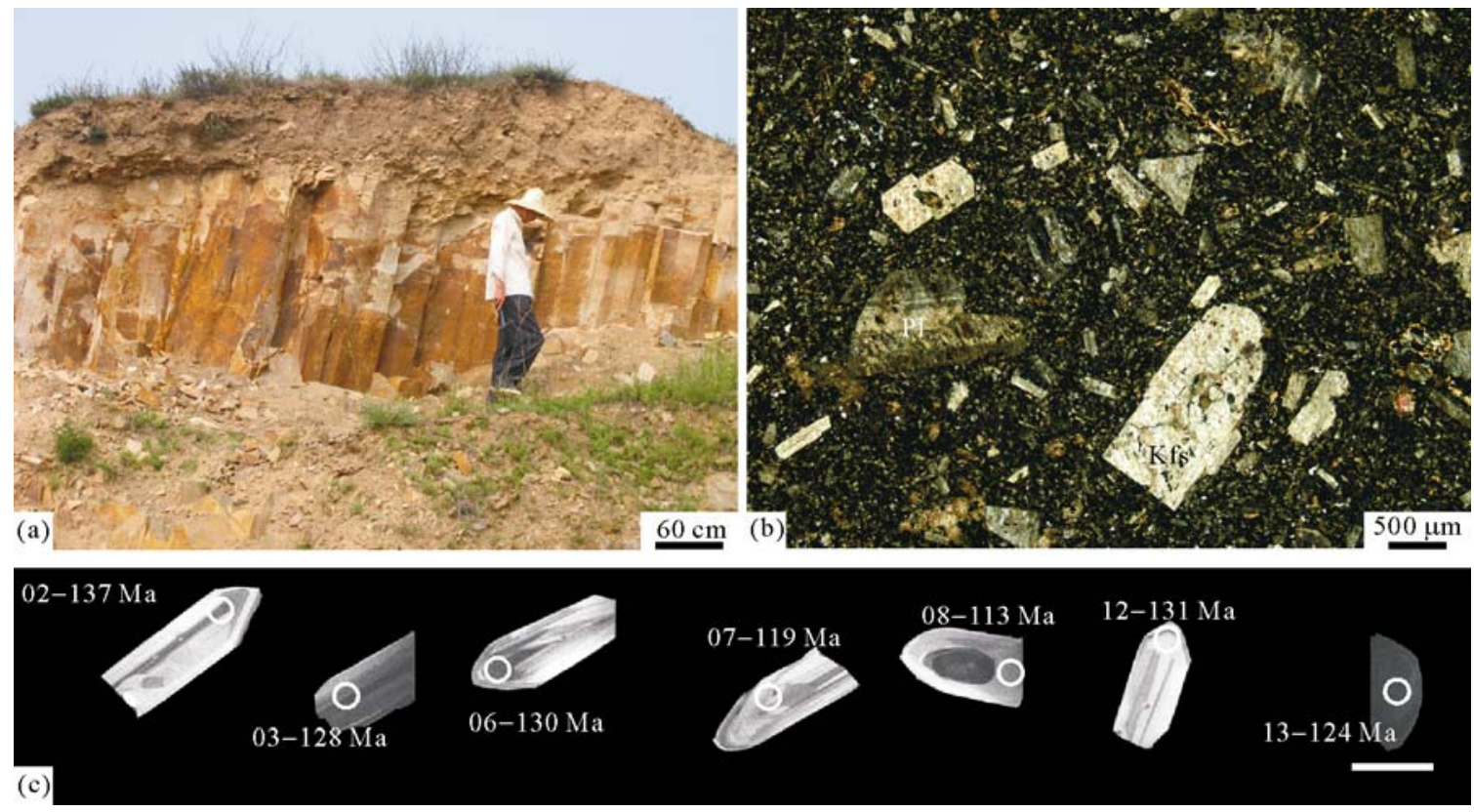

图 5 瓦房店-普兰店盆地火山岩(玉皇顶安山岩, SL0585)宏观和微观构造特征

(a) 安山岩柱状节理; (b) 斜长石和钾长石呈斑晶, 斜长质发育聚片双晶, 基质为交织结构; (c) 安山岩锆石阴极发光图像、测点及年龄值, 比 例尺为 $100 \mu \mathrm{m}$ 

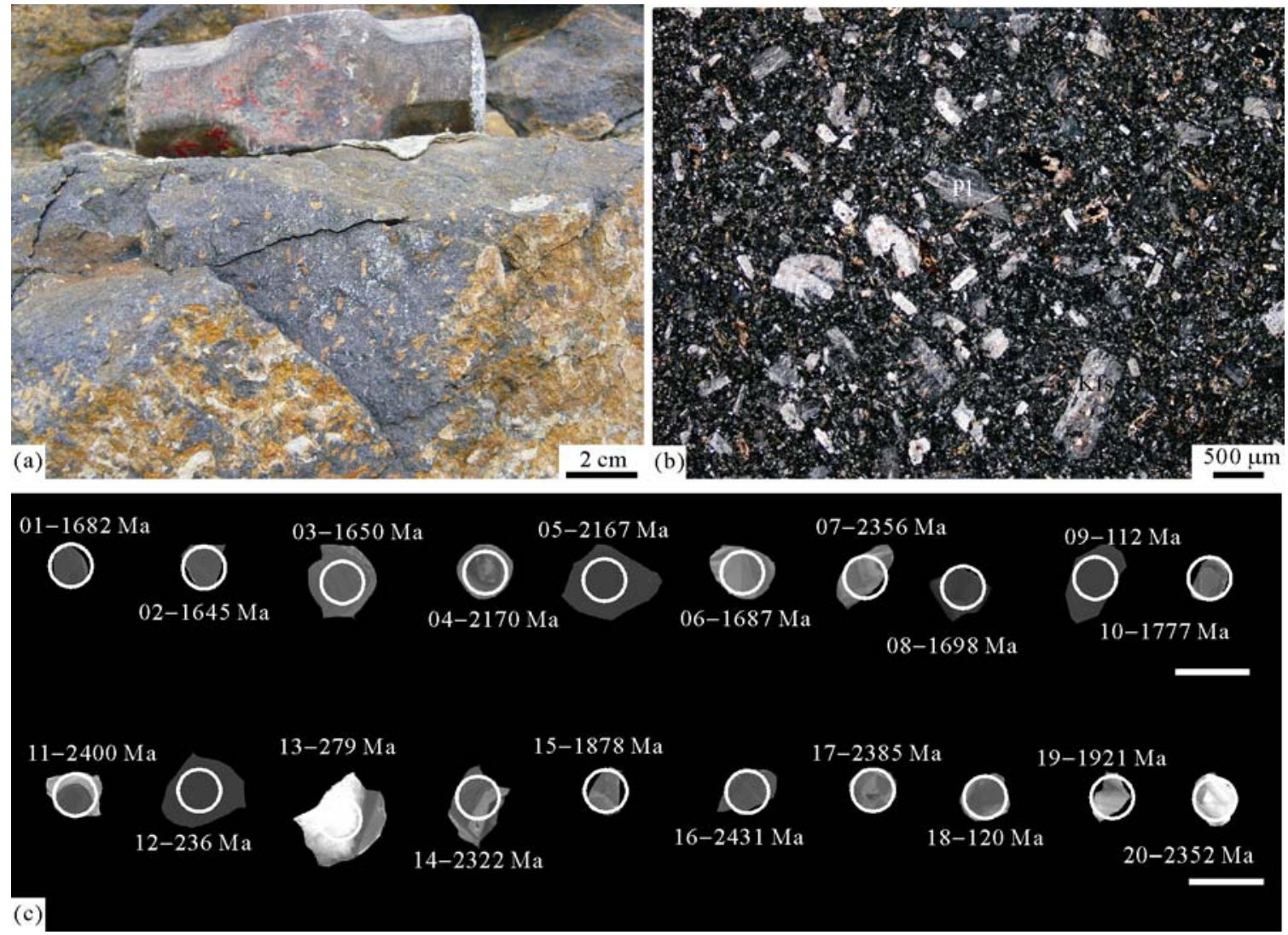

图 6 桂云花盆地火山岩(安山岩,SL05128)宏观和微观构造特征

(a) 露头可见长石斑晶, 基质为隐晶质; (b) 斜长石呈斑晶, 具交织结构; (c) 锆石阴极发光图像、测点及年龄值, 比例尺为 $100 \mu \mathrm{m}$
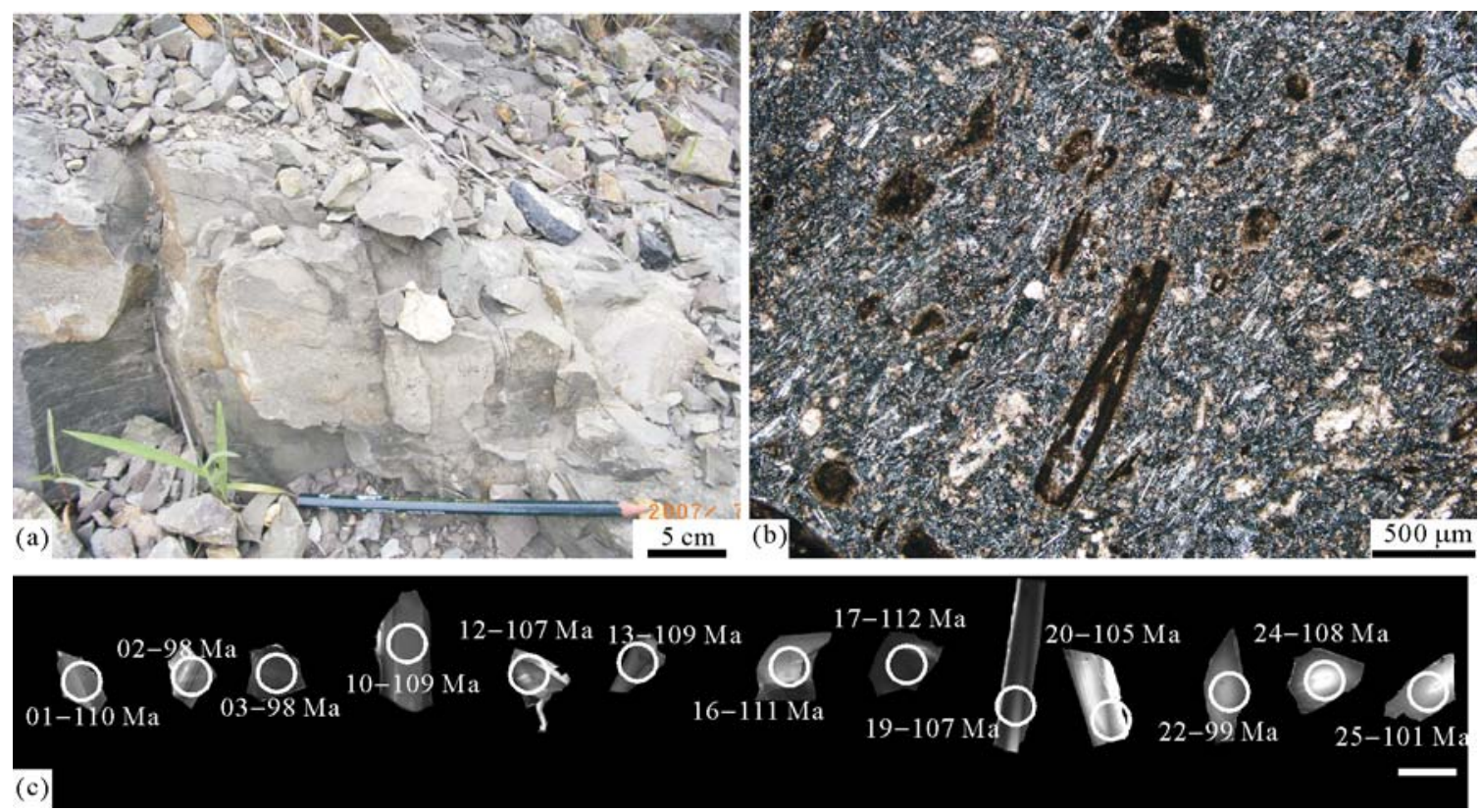

图 7 丹东火山岩(安山岩, SL0768)宏观和微观构造特征

(a) 野外产状; (b) 玟状角闪石暗化, 保留假象呈长柱状; (c) 锆石阴极发光图像、测点及年龄值, 比例尺为 $100 \mu \mathrm{m}$ 

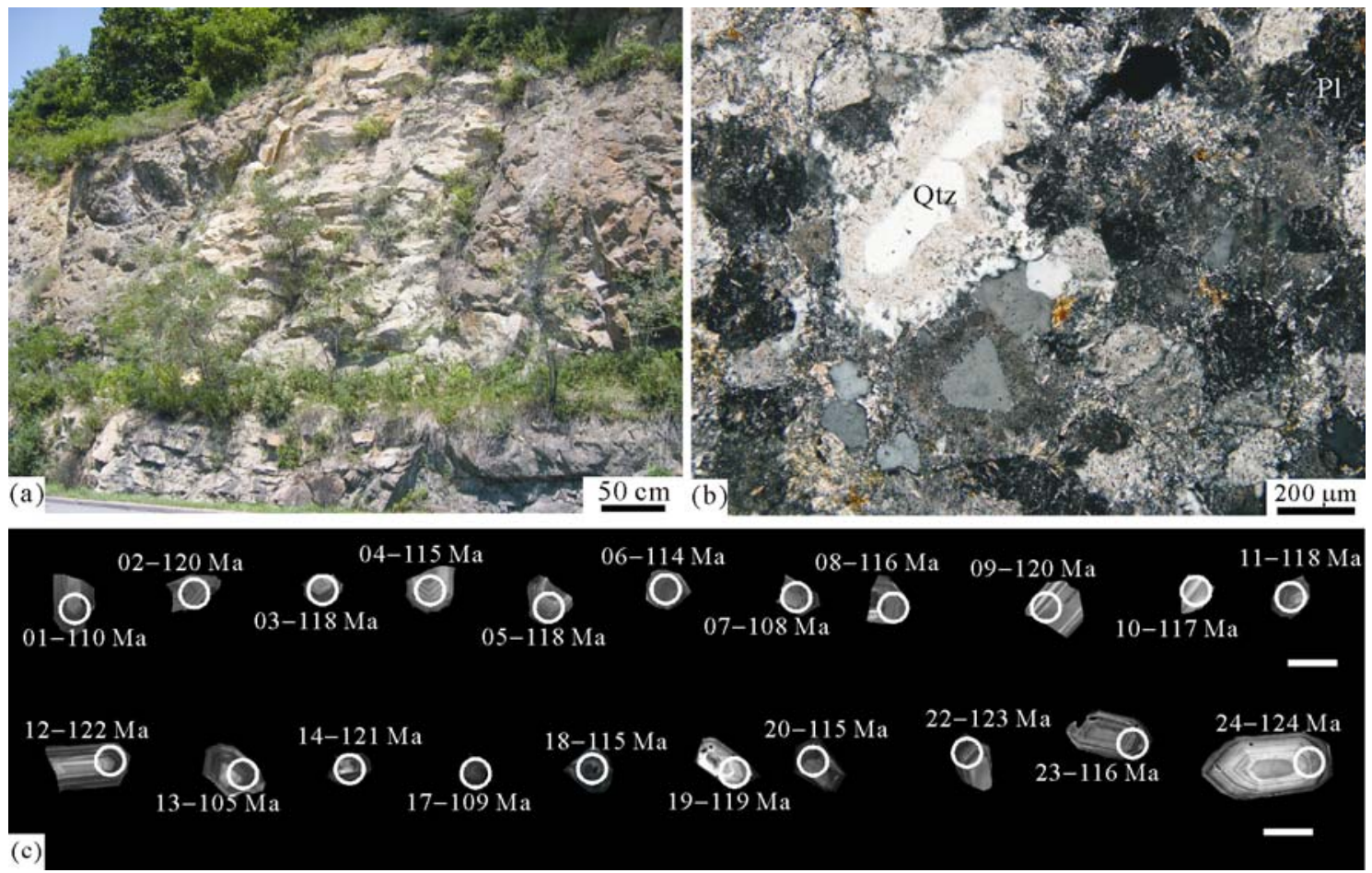

图 8 通远堡盆地侵入火山岩内的花岗岩脉(SL0734-4)宏观和微观构造特征

(a) 花岗质岩脉侵入安山岩(SL0734-4); (b) 长石和石英近等粒状, 石英斑晶具熔蚀和交代边; (c) 锆石阴极发光图像、测点及年龄值, 比例尺 为 $100 \mu \mathrm{m}$
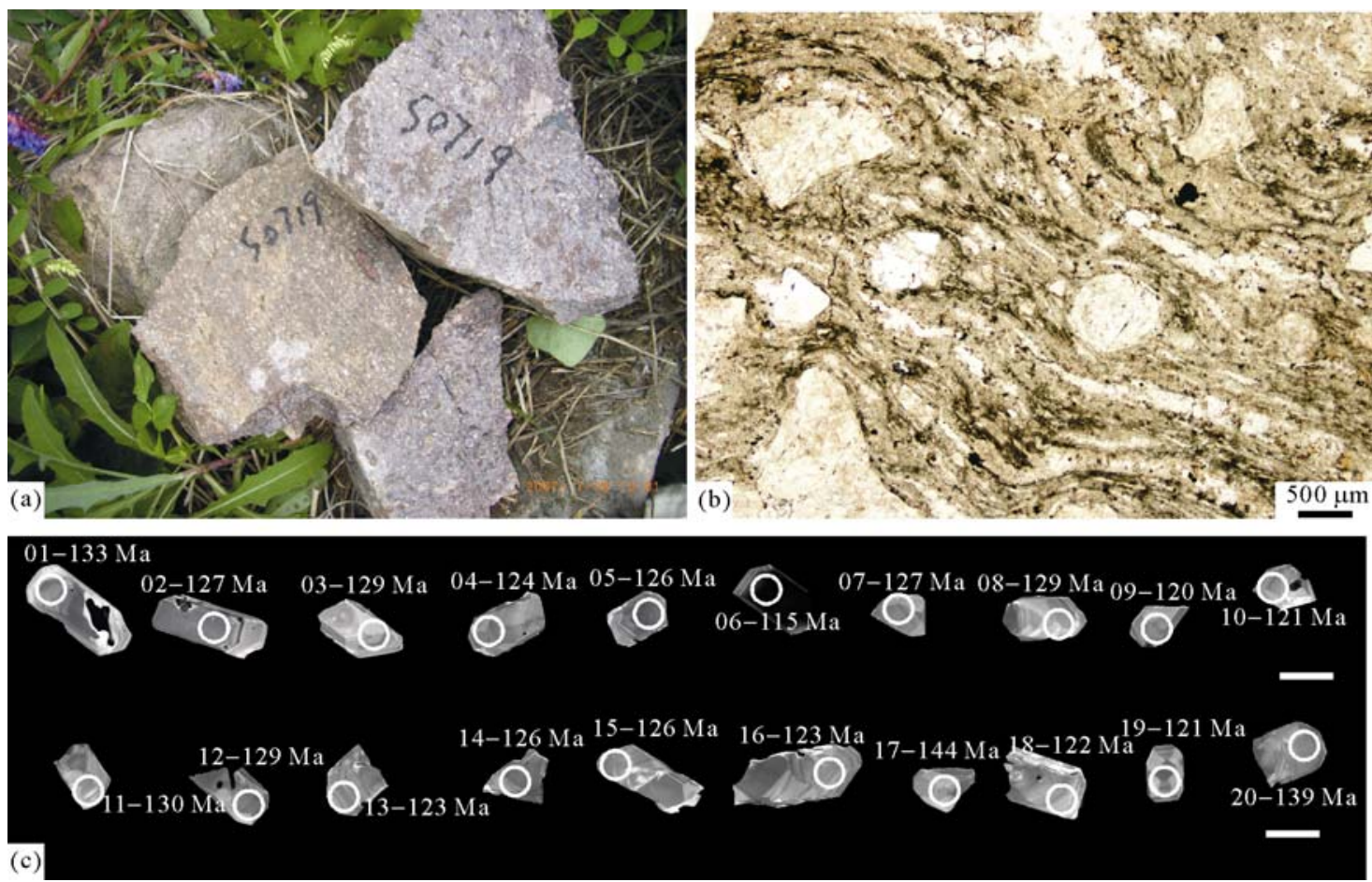

图 9 本溪盆地火山岩(流纹岩, SL0719)宏观和微观构造特征

(a) 岩石整体呈紫红色，长石呈斑晶; (b) 斜长石和石英呈斑晶, 发育流纹构造; (c) 锆石阴极发光图像、测点及年龄值, 比例尺为 $100 \mu \mathrm{m}$ 


\section{2 测试方法}

将采集的新鲜测年样品(约 2 3 kg)进行粉碎、淘 洗和磁选后，在双目显微镜下挑选晶型完好、无裂纹 和具有代表性的锆石颗粒进行制靶和抛光.

SHRIMP U-Pb 测年的 SL0585 安山岩的锆石, 其 阴极发光 CL 图像在中国地质科学院 JOEL JXA-8900RL 上进行采集. SHRIMP U-Pb 分析则在北 京离子探针中心 SHRIMP II 上完成, 并采用 TEM (约 $417 \mathrm{Ma},{ }^{206} \mathrm{~Pb} /{ }^{238} \mathrm{U}=0.06683$ ) 标样进行校正, 详细 的分析流程和原理参见文献 $[13,14]$. 年龄数据(在 ISOPLOT 软件上进行计算 ${ }^{[13]}$ )采用 ${ }^{206} \mathrm{~Pb} /{ }^{238} \mathrm{U}$ 加权平 均年龄, 分析误差为 $1 \sigma$, 具有 $95 \%$ 的置信度.

其余 4 个样品的锆石 CL 图像采集和 LA-ICPMS $\mathrm{U}-\mathrm{Pb}$ 测年分析在中国科学院地质与地球物理研究所 进行，具体流程参见文献 [15]. 测年数据利用 Glitter4.0 软件对锆石的同位素以及元素含量进行计 算, 参考锆石 91500(年龄 $1064 \mathrm{Ma}$ )和 NIST SRM 610 进行元素分馏校正, 具体方法见文献[16 18]. 3 个样 品的年龄数据采用 ${ }^{206} \mathrm{~Pb} /{ }^{238} \mathrm{U}$ 加权平均年龄; 1 个年龄 大于 $1 \mathrm{Ga}$ 的锆石采用 ${ }^{207} \mathrm{~Pb} /{ }^{206} \mathrm{~Pb}$ 年龄进行讨论(在 ISOPLOT 3.7 上进行计算), 分析误差为 $1 \sigma$.

\section{3 测试结果}

普兰店-瓦房店盆地玉皇顶安山岩(样品 SL0585) 颗粒粒度较小, 以浅黄色为主, 锆石轴长宽比 1.3 3.7, 呈短柱-长柱状, 发育岩浆振荡环带(图 5(c)), 且绝大部分锆石的 $\mathrm{Th}^{232} / \mathrm{U}^{238}=0.38 \sim 1.60>0.20$ (表 2), 故为典型的岩浆锆石. 共测定 13 个颗粒的 13 个测点, 其中, 测点 10 和 11 中普通铅含量达到 20\%左右, 明 显太高, 可能会导致过量扣除普通铅, 使年龄偏小, 所以取 7 个测点的 ${ }^{206} \mathrm{~Pb} /{ }^{238} \mathrm{U}$ 年龄加权平均为 $(126 \pm 6)$ $\mathrm{Ma}(95 \%$ 置信度, $\mathrm{MSWD}=2.2$, 图 10).

桂云花盆地里的安山岩(样品 SL05128)以浅黄色 为主, 颗粒较小, 粒径不均匀, $20 \sim 75 \mu \mathrm{m}$, 多为碎片, 有的呈浑圆状，阴极发光图像中，锆石发育岩浆韵律 和带状环带(图 6(c)), 且普遍的 ${ }^{232} \mathrm{Th} /{ }^{238} \mathrm{U}>0.2$ (表 2), 故为典型的岩浆锆石. 共测定 20 个颗粒的 20 个测点, 其中 8 个测点 ${ }^{207} \mathrm{~Pb} /{ }^{206} \mathrm{~Pb}$ 加权平均年龄为 $(2323 \pm 40)$ $\mathrm{Ma}(95 \%$ 置信度, $\mathrm{MSWD}=9.5$, 误差 $1 \sigma$ ), 9 个测点平均 年龄为 $(1747 \pm 60) \mathrm{Ma}(95 \%$ 置信度, $\mathrm{MSWD}=17$, 误差 $1 \sigma$ ), 另有几个颗粒具有 $279 \sim 112 \mathrm{Ma}$ 的年龄值. 锆石
U-Pb 谐和线图上的不一致线(图 10)给出了太古代和 元古代的年龄. 它们是原岩部分熔融残余或者是岩 浆上升过程中捕获围岩中的锆石颗粒. 只有两个年 轻的年龄(120 和 $112 \mathrm{Ma}$ )代表着火山作用的年龄.

大营子盆地内桂云花组安山岩(样品 SL0826)和 黄花甸盆地桂云花组流纹岩(样品 SL06078)年龄分别 为(132 \pm 5$) \mathrm{Ma}(95 \%$ 置信度, $M S W D=11.7$, 误差 $1 \sigma$ ) 和 $(135 \pm 1) \mathrm{Ma}(92 \% \text { 置信度, } \mathrm{MSWD}=1.3 \text {, 误差 } 2 \sigma)^{[12]}$.二 者记载了两个盆地火山作用的年龄, 进而表明控盆 断层作用的活动年龄.

丹东桂云花组安山岩(样品 SL0768)锆石颗粒无 色-淡黄色, 透明金刚光泽, 长短轴比 $1.5: 1 \sim 3: 1$, 多 为浑圆柱状或碎片状. 阴极发光图像中, 发育与柱面 方向平行的条带, 阴极发光性弱(图 7(c)). $\mathrm{Th}^{232} / \mathrm{U}^{238}=$ $0.63 \sim 2.44>0.2$ (表 2 ), 表明为岩浆锆石. 年代学分析 测定 26 个颗粒的 26 个测点, 去除 ${ }^{207} \mathrm{~Pb} /{ }^{206} \mathrm{~Pb}$, ${ }^{207} \mathrm{~Pb} /{ }^{235} \mathrm{U}$ 和 ${ }^{206} \mathrm{~Pb} /{ }^{238} \mathrm{U}$ 年龄谐和度不好的年龄, 选取 13 个测点进行加权平均, 获得年龄 $(106 \pm 3) \mathrm{Ma}(95 \%$ 置信度, $\mathrm{MSWD}=2.4$, 误差 $1 \sigma$ )(图 7(c) 和 10).

通远堡盆地中花岗质岩脉(样品 SL0734-4)锆石 颗粒无色-淡黄色, 透明玻璃光泽, 粒度较均匀, 粒径 75 150 $\mu \mathrm{m}$, 半自形-自形, 短柱状-长柱状, 长短轴比 $1: 1 \sim 2.5: 1$, 内部可见大量暗色包体. 阴极发光图像 中, 可见岩浆韵律环带 (图 $8\left(\mathrm{c}\right.$ )), 且 ${ }^{232} \mathrm{Th} /{ }^{238} \mathrm{U}=$ $0.56 \sim 1.43>0.2$ (表 2), 表明为典型的岩浆锆石. 年代 学分析选取 26 个锆石颗粒的 26 个测点进行分析, 去 除 ${ }^{207} \mathrm{~Pb} /{ }^{206} \mathrm{~Pb},{ }^{207} \mathrm{~Pb} /{ }^{235} \mathrm{U}$ 和 ${ }^{206} \mathrm{~Pb} /{ }^{238} \mathrm{U}$ 年龄不谐和的测 试点, 选取 21 个测点年龄进行加权平均, 获得年龄 (116 \pm 2$) \mathrm{Ma}(95 \%$ 置信度, MSWD=2.4, 图 10).

本溪桂云花组流纹岩(SL0719)锆石颗粒无色-淡 黄色, 粒度均匀, 粒径 50 100 $\mu \mathrm{m}$, 透明玻璃光泽, 自形长柱状, 多数破裂呈断片, 发育不规则熔蚀边. 阴极发光图像中可见清晰的岩浆韵律环带和扇状分 带(图 9(c)), 且 $\mathrm{Th}^{232} / \mathrm{U}^{238}=0.41 \sim 0.81>0.2$ (表 2), 表明 为典型的岩浆锆石. 年代学分析选取 20 个锆石颗粒 的 20 个测点分析, 获得加权平均年龄为 $(126 \pm 3)$ $\mathrm{Ma}(95 \%$ 置信度, $\mathrm{MSWD}=1.60$, 图 10).

\section{3 伸展构造组合特点与区域构造意义讨论}

辽东地区是华北克拉通晚中生代破坏与岩石圈 
表 2 辽东半岛伸展盆地中火山岩锆石 U-Pb 测年数据 ${ }^{\text {a) }}$

\begin{tabular}{|c|c|c|c|c|c|c|c|c|c|c|c|c|c|}
\hline 样品编号 & $\begin{array}{c}{ }^{206} \mathrm{~Pb}_{\mathrm{c}} \\
(\%)\end{array}$ & $\begin{array}{c}\mathrm{U} \\
\left(\mu \mathrm{g} \mathrm{g}^{-1}\right)\end{array}$ & $\begin{array}{c}\mathrm{Th} \\
\left(\mu \mathrm{g} \mathrm{g}^{-1}\right)\end{array}$ & $\begin{array}{l}{ }^{232} \mathrm{Th} \\
{ }^{238} \mathrm{U}\end{array}$ & $\begin{array}{l}{ }^{207} \mathrm{~Pb} \\
{ }^{206} \mathrm{~Pb}\end{array}$ & $1 \sigma(\%)$ & $\begin{array}{l}{ }^{207} \mathrm{~Pb} \\
/^{235} \mathrm{U}\end{array}$ & $1 \sigma(\%)$ & $\begin{array}{l}{ }^{206} \mathrm{~Pb} \\
{ }^{238} \mathrm{U}\end{array}$ & $1 \sigma(\%)$ & $\begin{array}{c}{ }^{207} \mathrm{~Pb} /{ }^{206} \mathrm{~Pb} \\
\pm 1 \sigma \\
(\mathrm{Ma}) \\
\end{array}$ & $\begin{array}{c}{ }^{207} \mathrm{~Pb} /{ }^{235} \mathrm{U} \\
\pm 1 \sigma \\
(\mathrm{Ma})\end{array}$ & $\begin{array}{c}{ }^{206} \mathrm{~Pb} /{ }^{238} \mathrm{U} \\
\pm 1 \sigma \\
(\mathrm{Ma}) \\
\end{array}$ \\
\hline \multicolumn{14}{|l|}{ SHRIMP } \\
\hline SL0585-1 & 1.36 & 133 & 49 & 0.38 & 0.06 & 3.8 & 0.18 & 8.6 & 0.03 & 3.3 & $18 \pm 191$ & - & $176 \pm 6$ \\
\hline SL0585-2 & 2.20 & 156 & 116 & 0.77 & 0.06 & 4.9 & 0.13 & 23.7 & 0.02 & 5.2 & $-113 \pm 570$ & - & $138 \pm 7$ \\
\hline SL0585-3 & 0.81 & 616 & 954 & 1.60 & 0.05 & 2.4 & 0.12 & 4.7 & 0.02 & 3.1 & $-196 \pm 90$ & - & $128 \pm 4$ \\
\hline SL0585-5 & 1.94 & 55 & 50 & 0.93 & 0.30 & 11 & 2.56 & 12.3 & 0.07 & 3.6 & $3392 \pm 184$ & - & $407 \pm 14$ \\
\hline SL0585-6 & 0.48 & 446 & 351 & 0.81 & 0.05 & 2.2 & 0.14 & 5.5 & 0.02 & 3.5 & $119 \pm 101$ & - & $130 \pm 5$ \\
\hline SL0585-7 & 1.77 & 104 & 111 & 1.10 & 0.09 & 4.4 & 0.21 & 14.7 & 0.019 & 3.8 & $1232 \pm 278$ & - & $120 \pm 5$ \\
\hline SL0585-8 & - & 40 & 30 & 0.76 & 0.07 & 9.4 & 0.20 & 9.1 & 0.018 & 4.2 & $1194 \pm 158$ & - & $113 \pm 5$ \\
\hline SL0585-9 & 0.05 & 248 & 194 & 0.81 & 0.17 & 2.0 & 10.70 & 3.6 & 0.46 & 3.0 & $2565 \pm 33$ & - & $2415 \pm 61$ \\
\hline SL0585-10 & 21.09 & 66 & 42 & 0.66 & 0.15 & 5.8 & - & - & 0.02 & 8.5 & - & - & $104 \pm 9$ \\
\hline SL0585-11 & 16.01 & 50 & 39 & 0.81 & 0.12 & 5.5 & - & - & 0.02 & 6.0 & - & - & $109 \pm 7$ \\
\hline SL0585-12 & 1.83 & 147 & 2 & 0.01 & 0.07 & 4.6 & 0.15 & 13.6 & 0.02 & 4.9 & $299 \pm 291$ & - & $131 \pm 6$ \\
\hline SL0585-13 & - & 99 & 87 & 0.91 & 0.09 & 6.9 & 0.26 & 9.6 & 0.02 & 7.2 & $1577 \pm 118$ & - & $124 \pm 9$ \\
\hline 样品编号 & $\begin{array}{c}\mathrm{Pb} \\
\left(\mu \mathrm{g} \mathrm{g}^{-1}\right)\end{array}$ & $\begin{array}{c}\mathrm{U} \\
\left(\mu \mathrm{g} \mathrm{g}^{-1}\right)\end{array}$ & $\begin{array}{c}\mathrm{Th} \\
\left(\mu \mathrm{g} \mathrm{g}^{-1}\right)\end{array}$ & $\begin{array}{l}{ }^{232} \mathrm{Th} \\
{ }^{238} \mathrm{U}\end{array}$ & $\begin{array}{l}{ }^{207} \mathrm{~Pb} \\
{ }^{206} \mathrm{~Pb}\end{array}$ & $1 \sigma$ & $\begin{array}{l}{ }^{207} \mathrm{~Pb} \\
/^{235} \mathrm{U}\end{array}$ & $1 \sigma$ & $\begin{array}{l}{ }^{206} \mathrm{~Pb} \\
{ }^{238} \mathrm{U}\end{array}$ & $1 \sigma$ & $\begin{array}{c}{ }^{207} \mathrm{~Pb} /{ }^{206} \mathrm{~Pb} \\
\pm 1 \sigma \\
(\mathrm{Ma}) \\
\end{array}$ & $\begin{array}{c}{ }^{207} \mathrm{~Pb} /{ }^{235} \mathrm{U} \\
\pm 1 \sigma \\
(\mathrm{Ma}) \\
\end{array}$ & $\begin{array}{c}{ }^{206} \mathrm{~Pb} /{ }^{238} \mathrm{U} \\
\pm 1 \sigma \\
(\mathrm{Ma}) \\
\end{array}$ \\
\hline \multicolumn{14}{|l|}{ LA-ICPMS } \\
\hline SL05128-01 & 1190.35 & 869 & 143 & 0.16 & 0.10 & 0.00108 & 5.03 & 0.05947 & 0.35 & 0.00869 & $1682 \pm 28$ & $1824 \pm 10$ & $1951 \pm 41$ \\
\hline SL05128-02 & 504.16 & 394 & 304 & 0.77 & 0.10 & 0.00106 & 5.02 & 0.05957 & 0.36 & 0.00882 & $1645 \pm 28$ & $1823 \pm 10$ & $1982 \pm 42$ \\
\hline SL05128-03 & 460.28 & 368 & 104 & 0.28 & 0.10 & 0.00134 & 4.94 & 0.0686 & 0.35 & 0.00885 & $1650 \pm 26$ & $1808 \pm 12$ & $1949 \pm 42$ \\
\hline SL05128-04 & 1245.71 & 763 & 303 & 0.40 & 0.14 & 0.00122 & 8.37 & 0.09062 & 0.45 & 0.01083 & $2170 \pm 27$ & $2272 \pm 10$ & $2386 \pm 48$ \\
\hline SL05128-05 & 15.08 & 13 & 4 & 0.30 & 0.14 & 0.00842 & 6.01 & 0.30041 & 0.32 & 0.01199 & $2167 \pm 112$ & $1978 \pm 43$ & $1802 \pm 58$ \\
\hline SL05128-06 & 245.40 & 200 & 117 & 0.59 & 0.10 & 0.00131 & 4.84 & 0.06516 & 0.34 & 0.00839 & $1687 \pm 26$ & $1792 \pm 11$ & $1882 \pm 40$ \\
\hline SL05128-07 & 342.16 & 205 & 143 & 0.69 & 0.15 & 0.00162 & 9.55 & 0.11497 & 0.46 & 0.01121 & $2356 \pm 25$ & $2393 \pm 11$ & $2433 \pm 50$ \\
\hline SL05128-08 & 482.20 & 462 & 223 & 0.48 & 0.10 & 0.00122 & 4.12 & 0.05217 & 0.29 & 0.00699 & $1698 \pm 27$ & $1658 \pm 10$ & $1625 \pm 35$ \\
\hline SL05128-09 & 547.93 & 8332 & 3959 & 0.48 & 0.06 & 0.00309 & 0.14 & 0.00652 & 0.02 & 0.00044 & $557 \pm 118$ & $134 \pm 6$ & $112 \pm 3$ \\
\hline SL05128-10 & 356.12 & 340 & 81 & 0.24 & 0.11 & 0.00135 & 3.96 & 0.0522 & 0.26 & 0.00646 & $1777 \pm 26$ & $1627 \pm 11$ & $1511 \pm 33$ \\
\hline SL05128-11 & 573.45 & 341 & 143 & 0.42 & 0.15 & 0.00161 & 9.08 & 0.10675 & 0.43 & 0.01018 & $2400 \pm 25$ & $2347 \pm 11$ & $2283 \pm 46$ \\
\hline SL05128-12 & 16.40 & 95 & 136 & 1.43 & 0.11 & 0.01856 & 0.56 & 0.09082 & 0.04 & 0.00195 & $1788 \pm 333$ & $453 \pm 59$ & $236 \pm 12$ \\
\hline SL05128-13 & 12.19 & 74 & 11 & 0.15 & 0.05 & 0.00407 & 0.33 & 0.02284 & 0.04 & 0.00176 & $361 \pm 88$ & $288 \pm 17$ & $279 \pm 11$ \\
\hline SL05128-14 & 451.56 & 317 & 92 & 0.29 & 0.15 & 0.00169 & 7.81 & 0.09716 & 0.38 & 0.00918 & $2322 \pm 24$ & $2209 \pm 11$ & $2087 \pm 43$ \\
\hline SL05128-15 & 319.02 & 265 & 93 & 0.35 & 0.11 & 0.00153 & 5.41 & 0.07501 & 0.34 & 0.00828 & $1878 \pm 24$ & $1886 \pm 12$ & $1891 \pm 40$ \\
\hline SL05128-16 & 162.14 & 114 & 94 & 0.82 & 0.16 & 0.00326 & 8.51 & 0.16785 & 0.39 & 0.01072 & $2431 \pm 22$ & $2287 \pm 18$ & $2127 \pm 50$ \\
\hline SL05128-17 & 303.40 & 213 & 105 & 0.50 & 0.15 & 0.00547 & 7.73 & 0.18997 & 0.37 & 0.00943 & $2385 \pm 62$ & $2200 \pm 22$ & $2008 \pm 45$ \\
\hline SL05128-18 & 58.25 & 738 & 439 & 0.60 & 0.07 & 0.00639 & 0.18 & 0.01552 & 0.02 & 0.00059 & $907 \pm 197$ & $167 \pm 13$ & $120 \pm 4$ \\
\hline SL05128-19 & 107.09 & 112 & 96 & 0.86 & 0.12 & 0.00234 & 4.03 & 0.07621 & 0.25 & 0.00645 & $1921 \pm 22$ & $1641 \pm 15$ & $1430 \pm 33$ \\
\hline SL05128-20 & 332.31 & 273 & 123 & 0.45 & 0.15 & 0.00236 & 7.85 & 0.12278 & 0.38 & 0.00946 & $2352 \pm 23$ & $2214 \pm 14$ & $2066 \pm 44$ \\
\hline SL0768-01 & 19.46 & 273 & 424 & 1.54 & 0.07 & 0.00374 & 0.16 & 0.00792 & 0.02 & 0.00056 & $797 \pm 55$ & $147 \pm 7$ & $110 \pm 4$ \\
\hline SL0768-02 & 28.53 & 381 & 605 & 1.59 & 0.06 & 0.01331 & 0.13 & 0.02743 & 0.02 & 0.0007 & $624 \pm 456$ & $122 \pm 25$ & $98 \pm 4$ \\
\hline SL0768-03 & 31.83 & 528 & 1059 & 2.00 & 0.05 & 0.00315 & 0.10 & 0.00611 & 0.02 & 0.0005 & $60 \pm 77$ & $96 \pm 6$ & $98 \pm 3$ \\
\hline SL0768-04 & 27.12 & 399 & 640 & 1.61 & 0.052 & 0.00296 & 0.12 & 0.00639 & 0.02 & 0.00051 & $295 \pm 66$ & $117 \pm 6$ & $109 \pm 3$ \\
\hline SL0768-05 & 32.78 & 428 & 724 & 1.69 & 0.05 & 0.00796 & 0.09 & 0.0154 & 0.01 & 0.00074 & \pm 302 & $90 \pm 14$ & $94 \pm 5$ \\
\hline SL0768-06 & 48.09 & 817 & 1432 & 1.75 & 0.04 & 0.00799 & 0.09 & 0.01545 & 0.02 & 0.00104 & $-29 \pm 209$ & $90 \pm 14$ & $96 \pm 7$ \\
\hline SL0768-07 & 5.31 & 72 & 45 & 0.63 & 0.07 & 0.0201 & 0.15 & 0.04182 & 0.02 & 0.00114 & $960 \pm 601$ & $145 \pm 37$ & $100 \pm 7$ \\
\hline SL0768-08 & 18.17 & 209 & 306 & 1.47 & 0.08 & 0.01569 & 0.20 & 0.03919 & 0.02 & 0.00087 & $1098 \pm 451$ & $181 \pm 33$ & $119 \pm 5$ \\
\hline SL0768-09 & 15.35 & 206 & 317 & 1.54 & 0.05 & 0.00603 & 0.13 & 0.01476 & 0.02 & 0.00082 & $261 \pm 170$ & $127 \pm 13$ & $120 \pm 5$ \\
\hline SL0768-10 & 26.31 & 387 & 715 & 1.85 & 0.05 & 0.00339 & 0.11 & 0.00737 & 0.02 & 0.00058 & $136 \pm 85$ & $110 \pm 7$ & $109 \pm 4$ \\
\hline
\end{tabular}


续(表 2)

\begin{tabular}{|c|c|c|c|c|c|c|c|c|c|c|c|c|c|}
\hline 样品编号 & $\begin{array}{c}\mathrm{Pb} \\
\left(\mu \mathrm{g} \mathrm{g}^{-1}\right)\end{array}$ & $\begin{array}{c}\mathrm{U} \\
\left(\mu \mathrm{g} \mathrm{g}^{-1}\right)\end{array}$ & $\begin{array}{c}\mathrm{Th} \\
\left(\mu \mathrm{g} \mathrm{g}^{-1}\right)\end{array}$ & $\begin{array}{l}{ }^{232} \mathrm{Th} \\
{ }^{238} \mathrm{U}\end{array}$ & $\begin{array}{l}{ }^{207} \mathrm{~Pb} \\
{ }^{206} \mathrm{~Pb}\end{array}$ & $1 \sigma$ & $\begin{array}{l}{ }^{207} \mathrm{~Pb} \\
{ }^{235} \mathrm{U}\end{array}$ & $1 \sigma$ & $\begin{array}{l}{ }^{206} \mathrm{~Pb} \\
{ }^{238} \mathrm{U}\end{array}$ & $1 \sigma$ & $\begin{array}{c}{ }^{207} \mathrm{~Pb} /{ }^{206} \mathrm{~Pb} \\
\pm 1 \sigma \\
(\mathrm{Ma}) \\
\end{array}$ & $\begin{array}{c}{ }^{207} \mathrm{~Pb} /{ }^{235} \mathrm{U} \\
\pm 1 \sigma \\
(\mathrm{Ma}) \\
\end{array}$ & $\begin{array}{c}{ }^{206} \mathrm{~Pb} /{ }^{238} \mathrm{U} \\
\pm 1 \sigma \\
(\mathrm{Ma}) \\
\end{array}$ \\
\hline SL0768-11 & 25.83 & 414 & 945 & 2.27 & 0.07 & 0.00274 & 0.16 & 0.00523 & 0.02 & 0.0004 & $1059 \pm 31$ & $149 \pm 5$ & $98 \pm 3$ \\
\hline SL0768-12 & 26.75 & 402 & 710 & 1.75 & 0.05 & 0.00215 & 0.11 & 0.00463 & 0.02 & 0.00043 & $120 \pm 52$ & $107 \pm 4$ & $107 \pm 3$ \\
\hline SL0768-13 & 21.69 & 309 & 531 & 1.72 & 0.05 & 0.00293 & 0.11 & 0.00635 & 0.02 & 0.00054 & $43 \pm 70$ & $106 \pm 6$ & $109 \pm 3$ \\
\hline SL0768-14 & 29.78 & 418 & 707 & 1.69 & 0.07 & 0.00268 & 0.16 & 0.00599 & 0.02 & 0.00048 & $809 \pm 37$ & $154 \pm 5$ & $115 \pm 3$ \\
\hline SL0768-15 & 31.26 & 511 & 836 & 1.64 & 0.07 & 0.0037 & 0.16 & 0.00757 & 0.02 & 0.00053 & $868 \pm 52$ & $147 \pm 7$ & $106 \pm 3$ \\
\hline SL0768-16 & 29.09 & 426 & 356 & 0.83 & 0.05 & 0.00202 & 0.12 & 0.00448 & 0.02 & 0.00043 & $289 \pm 41$ & $119 \pm 4$ & $111 \pm 3$ \\
\hline SL0768-17 & 61.56 & 895 & 2179 & 2.44 & 0.05 & 0.00278 & 0.12 & 0.00618 & 0.02 & 0.00053 & $195 \pm 65$ & $116 \pm 6$ & $112 \pm 3$ \\
\hline SL0768-18 & 29.11 & 400 & 708 & 1.79 & 0.05 & 0.00278 & 0.13 & 0.00647 & 0.02 & 0.00056 & $224 \pm 63$ & $123 \pm 6$ & $118 \pm 4$ \\
\hline SL0768-19 & 21.96 & 322 & 556 & 1.72 & 0.05 & 0.00271 & 0.12 & 0.00579 & 0.02 & 0.00048 & $307 \pm 59$ & $116 \pm 5$ & $107 \pm 3$ \\
\hline SL0768-20 & 8.57 & 123 & 144 & 1.163 & 0.05 & 0.01085 & 0.12 & 0.02386 & 0.02 & 0.00072 & $409 \pm 406$ & $119 \pm 22$ & $105 \pm 5$ \\
\hline SL0768-21 & 15.89 & 224 & 536 & 2.38 & 0.07 & 0.00411 & 0.17 & 0.00906 & 0.02 & 0.0006 & $897 \pm 58$ & $159 \pm 8$ & $114 \pm 4$ \\
\hline SL0768-22 & 26.50 & 390 & 508 & 1.30 & 0.05 & 0.00322 & 0.11 & 0.00627 & 0.02 & 0.00051 & $233 \pm 75$ & $104 \pm 6$ & $99 \pm 3$ \\
\hline SL0768-23 & 25.49 & 369 & 567 & 1.54 & 0.06 & 0.00331 & 0.14 & 0.0074 & 0.02 & 0.00056 & $528 \pm 61$ & $135 \pm 7$ & $114 \pm 4$ \\
\hline SL0768-24 & 18.49 & 279 & 504 & 1.82 & 0.05 & 0.0033 & 0.12 & 0.00707 & 0.02 & 0.00056 & $223 \pm 79$ & $113 \pm 6$ & $108 \pm 4$ \\
\hline SL0768-25 & 35.56 & 576 & 1113 & 1.92 & 0.05 & 0.00298 & 0.12 & 0.00594 & 0.02 & 0.00048 & $404 \pm 60$ & $114 \pm 5$ & $101 \pm 3$ \\
\hline SL0768-26 & 15.71 & 256 & 322 & 1.27 & 0.05 & 0.0066 & 0.10 & 0.01331 & 0.02 & 0.00067 & \pm 261 & $95 \pm 12$ & $98 \pm 4$ \\
\hline SL0734-4-01 & 28.80 & 413 & 335 & 0.81 & 0.07 & 0.00313 & 0.16 & 0.00671 & 0.02 & 0.00049 & $882 \pm 42$ & $153 \pm 6$ & $110 \pm 3$ \\
\hline SL0734-4-02 & 57.22 & 766 & 582 & 0.76 & 0.07 & 0.00617 & 0.18 & 0.01517 & 0.02 & 0.00054 & $898 \pm 191$ & $167 \pm 13$ & $120 \pm 3$ \\
\hline SL0734-4-03 & 25.31 & 350 & 261 & 0.75 & 0.06 & 0.00212 & 0.15 & 0.00495 & 0.02 & 0.00046 & $624 \pm 32$ & $146 \pm 4$ & $118 \pm 3$ \\
\hline SL0734-4-04 & 35.93 & 497 & 343 & 0.69 & 0.07 & 0.00705 & 0.17 & 0.01654 & 0.02 & 0.00058 & $930 \pm 215$ & $163 \pm 14$ & $115 \pm 4$ \\
\hline SL0734-4-05 & 34.94 & 484 & 402 & 0.83 & 0.07 & 0.00284 & 0.19 & 0.00644 & 0.02 & 0.0005 & $1044 \pm 32$ & $176 \pm 5$ & $118 \pm 3$ \\
\hline SL0734-4-06 & 41.70 & 599 & 350 & 0.58 & 0.06 & 0.00214 & 0.15 & 0.00479 & 0.02 & 0.00045 & $614 \pm 32$ & $140 \pm 4$ & $114 \pm 3$ \\
\hline SL0734-4-07 & 47.06 & 647 & 502 & 0.78 & 0.05 & 0.00684 & 0.12 & 0.01553 & 0.02 & 0.00053 & $333 \pm 292$ & $119 \pm 14$ & $108 \pm 3$ \\
\hline SL0734-4-08 & 59.59 & 814 & 656 & 0.81 & 0.08 & 0.0072 & 0.19 & 0.01697 & 0.02 & 0.00056 & $1127 \pm 193$ & $179 \pm 14$ & $116 \pm 4$ \\
\hline SL0734-4-09 & 36.92 & 508 & 377 & 0.74 & 0.06 & 0.00239 & 0.15 & 0.00564 & 0.02 & 0.00051 & $461 \pm 42$ & $138 \pm 5$ & $120 \pm 3$ \\
\hline SL0734-4-10 & 25.73 & 340 & 411 & 1.11 & 0.06 & 0.00302 & 0.15 & 0.00694 & 0.02 & 0.00053 & $641 \pm 50$ & $146 \pm 6$ & $117 \pm 3$ \\
\hline SL0734-4-11 & 40.17 & 517 & 504 & 0.97 & 0.07 & 0.00734 & 0.17 & 0.01801 & 0.02 & 0.00056 & $798 \pm 245$ & $157 \pm 16$ & $118 \pm 4$ \\
\hline SL0734-4-12 & 50.31 & 669 & 560 & 0.83 & 0.06 & 0.00605 & 0.17 & 0.01513 & 0.02 & 0.00056 & $765 \pm 205$ & $160 \pm 13$ & $122 \pm 4$ \\
\hline SL0734-4-13 & 66.77 & 1023 & 1308 & 1.28 & 0.07 & 0.0064 & 0.16 & 0.01378 & 0.02 & 0.00045 & $926 \pm 195$ & $149 \pm 12$ & $105 \pm 3$ \\
\hline SL0734-4-14 & 46.42 & 629 & 554 & 0.88 & 0.05 & 0.00169 & 0.14 & 0.00408 & 0.01899 & 0.00045 & $315 \pm 31$ & $131 \pm 4$ & $121 \pm 3$ \\
\hline SL0734-4-15 & 95.32 & 1302 & 1861 & 1.43 & 0.11 & 0.00819 & 0.26 & 0.0188 & 0.02 & 0.00051 & $1724 \pm 147$ & $235 \pm 15$ & $114 \pm 3$ \\
\hline SL0734-4-16 & 51.75 & 691 & 514 & 0.75 & 0.10 & 0.01027 & 0.22 & 0.02132 & 0.02 & 0.00052 & $1642 \pm 196$ & $203 \pm 18$ & $102 \pm 3$ \\
\hline SL0734-4-17 & 98.22 & 1389 & 1604 & 1.15 & 0.07 & 0.00666 & 0.18 & 0.01498 & 0.02 & 0.00046 & $1014 \pm 192$ & $161 \pm 13$ & $109 \pm 3$ \\
\hline SL0734-4-18 & 61.29 & 722 & 584 & 0.81 & 0.06 & 0.00842 & 0.15 & 0.02034 & 0.02 & 0.00057 & $623 \pm 314$ & $142 \pm 18$ & $115 \pm 4$ \\
\hline SL0734-4-19 & 17.25 & 232 & 160 & 0.69 & 0.06 & 0.00996 & 0.15 & 0.02458 & 0.02 & 0.00082 & $612 \pm 372$ & $146 \pm 22$ & $119 \pm 5$ \\
\hline SL0734-4-20 & 83.83 & 1165 & 1181 & 1.01 & 0.07 & 0.0051 & 0.17 & 0.01194 & 0.02 & 0.00045 & $828 \pm 165$ & $155 \pm 10$ & $115 \pm 3$ \\
\hline SL0734-4-21 & 36.38 & 440 & 279 & 0.63 & 0.05 & 0.00193 & 0.14 & 0.00515 & 0.02 & 0.00053 & $165 \pm 42$ & $135 \pm 5$ & $133 \pm 3$ \\
\hline SL0734-4-22 & 46.39 & 622 & 364 & 0.58 & 0.06 & 0.00575 & 0.16 & 0.01453 & 0.02 & 0.00057 & $558 \pm 222$ & $147 \pm 13$ & $123 \pm 4$ \\
\hline SL0734-4-23 & 51.17 & 672 & 540 & 0.81 & 0.07 & 0.0068 & 0.17 & 0.01623 & 0.02 & 0.00053 & $882 \pm 214$ & $160 \pm 14$ & $116 \pm 3$ \\
\hline SL0734-4-24 & 19.63 & 253 & 154 & 0.61 & 0.05 & 0.00271 & 0.13 & 0.00671 & 0.02 & 0.00058 & $125 \pm 67$ & $124 \pm 6$ & $124 \pm 4$ \\
\hline SL0734-4-25 & 49.95 & 630 & 466 & 0.74 & 0.06 & 0.00467 & 0.17 & 0.01219 & 0.02 & 0.00051 & $619 \pm 172$ & $157 \pm 11$ & $128 \pm 3$ \\
\hline SL0734-4-26 & 38.38 & 465 & 258 & 0.56 & 0.05 & 0.00184 & 0.15 & 0.00504 & 0.02 & 0.00053 & $258 \pm 36$ & $144 \pm 4$ & $137 \pm 3$ \\
\hline
\end{tabular}




\begin{tabular}{|c|c|c|c|c|c|c|c|c|c|c|c|c|c|}
\hline 样品编号 & $\begin{array}{c}\mathrm{Pb} \\
\left(\mu \mathrm{g} \mathrm{g}^{-1}\right)\end{array}$ & $\begin{array}{c}\mathrm{U} \\
\left(\mu \mathrm{g} \mathrm{g}^{-1}\right)\end{array}$ & $\begin{array}{c}\mathrm{Th} \\
\left(\mu \mathrm{g} \mathrm{g}^{-1}\right)\end{array}$ & $\begin{array}{l}\mathrm{Th}^{232} \\
/ \mathrm{U}^{238}\end{array}$ & $\begin{array}{l}{ }^{207} \mathrm{~Pb} \\
{ }^{206} \mathrm{~Pb}\end{array}$ & $1 \sigma$ & $\begin{array}{l}{ }^{207} \mathrm{~Pb} \\
{ }^{235} \mathrm{U}\end{array}$ & $1 \sigma$ & $\begin{array}{l}{ }^{206} \mathrm{~Pb} \\
{ }^{238} \mathrm{U}\end{array}$ & $1 \sigma$ & $\begin{array}{c}{ }^{207} \mathrm{~Pb} /{ }^{206} \mathrm{~Pb} \\
\pm 1 \sigma \\
(\mathrm{Ma})\end{array}$ & $\begin{array}{c}{ }^{207} \mathrm{~Pb} /{ }^{235} \mathrm{U} \\
\pm 1 \sigma \\
(\mathrm{Ma})\end{array}$ & $\begin{array}{c}{ }^{206} \mathrm{~Pb} /{ }^{238} \mathrm{U} \\
\pm 1 \sigma \\
(\mathrm{Ma})\end{array}$ \\
\hline SL0719-01 & 18.35 & 215 & 118 & 0.55 & 0.05 & 0.00225 & 0.14 & 0.00601 & 0.02 & 0.00055 & $123 \pm 54$ & $132 \pm 5$ & $133 \pm 3$ \\
\hline SL0719-02 & 12.43 & 148 & 83 & 0.56 & 0.05 & 0.00435 & 0.14 & 0.01084 & 0.02 & 0.0008 & $312 \pm 100$ & $136 \pm 10$ & $127 \pm 5$ \\
\hline SL0719-03 & 12.38 & 152 & 76 & 0.50 & 0.05 & 0.0026 & 0.13 & 0.0068 & 0.02 & 0.00055 & $123 \pm 68$ & $128 \pm 6$ & $129 \pm 3$ \\
\hline SL0719-04 & 11.43 & 142 & 66 & 0.46 & 0.05 & 0.00365 & 0.13 & 0.00905 & 0.02 & 0.00068 & $144 \pm 94$ & $125 \pm 8$ & $124 \pm 4$ \\
\hline SL0719-05 & 13.95 & 169 & 103 & 0.61 & 0.05 & 0.0032 & 0.14 & 0.00808 & 0.02 & 0.00064 & $230 \pm 77$ & $132 \pm 7$ & $126 \pm 4$ \\
\hline SL0719-06 & 89.90 & 1250 & 730 & 0.58 & 0.05 & 0.0011 & 0.1205 & 0.00258 & 0.02 & 0.0004 & $120 \pm 24$ & $116 \pm 2$ & $115 \pm 3$ \\
\hline SL0719-07 & 16.19 & 201 & 104 & 0.52 & 0.05 & 0.00402 & 0.14 & 0.01011 & 0.02 & 0.00079 & & & $127 \pm 5$ \\
\hline SL0719-08 & 12.13 & 149 & 66 & 0.44 & 0.05 & 0.00233 & 0.13 & 0.00604 & 0.02 & 0.00056 & $105 \pm 56$ & $128 \pm 5$ & $129 \pm 4$ \\
\hline SL0719-09 & 11.55 & 154 & 77 & 0.50 & 0.05 & 0.00319 & 0.13 & 0.00765 & 0.02 & 0.00062 & $114 \pm 80$ & $120 \pm 7$ & $120 \pm 4$ \\
\hline SL0719-10 & 13.29 & 172 & 82 & 0.48 & 0.05 & 0.00281 & 0.13 & 0.0068 & 0.02 & 0.00058 & $118 \pm 69$ & $121 \pm 6$ & $121 \pm 4$ \\
\hline SL0719-11 & 12.19 & 149 & 68 & 0.46 & 0.05 & 0.00276 & 0.14 & 0.00714 & 0.02 & 0.00062 & $162 \pm 66$ & $132 \pm 6$ & $130 \pm 4$ \\
\hline SL0719-12 & 14.40 & 166 & 78 & 0.47 & 0.05 & 0.00276 & 0.13 & 0.00706 & 0.02 & 0.00064 & $111 \pm 66$ & $128 \pm 6$ & $129 \pm 4$ \\
\hline SL0719-13 & 15.74 & 203 & 95 & 0.47 & 0.05 & 0.00228 & 0.13 & 0.00568 & 0.02 & 0.00054 & $107 \pm 54$ & $123 \pm 5$ & $123 \pm 3$ \\
\hline SL0719-14 & 12.93 & 161 & 69 & 0.43 & 0.05 & 0.00227 & 0.14 & 0.00571 & 0.02 & 0.00056 & $199 \pm 49$ & $130 \pm 5$ & $126 \pm 4$ \\
\hline SL0719-15 & 12.28 & 156 & 85 & 0.55 & 0.05 & 0.00307 & 0.14 & 0.00767 & 0.02 & 0.00065 & $223 \pm 70$ & $131 \pm 7$ & $126 \pm 4$ \\
\hline SL0719-16 & 11.62 & 145 & 60 & 0.41 & 0.05 & 0.00399 & 0.14 & 0.00964 & 0.02 & 0.00075 & $364 \pm 84$ & $136 \pm 9$ & $123 \pm 5$ \\
\hline SL0719-17 & 12.96 & 144 & 81 & 0.56 & 0.05 & 0.00349 & 0.14 & 0.00996 & 0.02 & 0.00081 & $248 \pm 80$ & $150 \pm 9$ & $144 \pm 5$ \\
\hline SL0719-18 & 12.35 & 163 & 84 & 0.52 & 0.05 & 0.0047 & 0.14 & 0.01124 & 0.02 & 0.00084 & $318 \pm 107$ & $132 \pm 10$ & $122 \pm 5$ \\
\hline SL0719-19 & 14.92 & 197 & 113 & 0.57 & 0.05 & 0.00271 & 0.13 & 0.00653 & 0.02 & 0.0006 & $161 \pm 62$ & $123 \pm 6$ & $121 \pm 4$ \\
\hline SL0719-20 & 15.84 & 184 & 149 & 0.81 & 0.05 & 0.00371 & 0.15 & 0.01023 & 0.02 & 0.00084 & $184 \pm 89$ & $142 \pm 9$ & $139 \pm 5$ \\
\hline
\end{tabular}

a) ${ }^{206} \mathrm{~Pb}_{\mathrm{c}}$ 为普通铅百分含量; $\mathrm{Pb}$ 为放射性成因

减薄最为强烈和典型的地区. 侏罗纪以来, 辽东地块 受到强烈的构造-岩浆活动性的改造, 尤其是在白严 纪达到鼎盛阶段. 这一阶段的构造-岩浆活动性, 是 华北克拉通岩石圈减薄和克拉通破坏的结果, 尤其 是在晚中生代, 伸展作用异常强烈. 在对于辽东半岛 西部辽南变质核杂岩深入研究的基础上, 在约 40000 $\mathrm{km}^{2}$ 范围内新近发现和厘定了数个新变质核杂岩构 造(包括万福、达子营)和许多拆离断层构造 ${ }^{[7,12]}$, 它们 的存在为阐明地壳的伸展与减薄提供了契机. 在伸 展构造的组成、结构、产状、运动学方式与动力学特 点等各个方面, 它们与华北克拉通区其他部位发育 的伸展构造具有统一性, 但是在伸展构造特点、切割 深度和发育时间等方面却存在着差异性.

\section{1 辽东半岛伸展构造共性}

辽东半岛伸展构造组合的发育是构造-岩浆-沉 积-变质作用的共同体, 其中主要包括了拆离断层作 用与变质核杂岩及伸展盆地的发育、大规模岩浆活动 (火山与侵入作用) 以及相应的角闪岩相-低绿片岩相 变质作用, 各种作用过程之间有着密切的成生联系
与变化. 对于辽南-万福变质核杂岩对、大营子-黄花 甸拆离断层系、通远堡、丹东和本溪等伸展断陷盆地 组合的研究, 揭示出以下相似性:

(1) 运动学的统一性. 尽管主拆离断层的延伸方 向可以有很大的变化, 但是辽东半岛地区的伸展构 造具有以 NWW-SEE 为主的伸展运动学指向, 区域 拉伸线理与断层擦痕的统计平均方向以 $\mathrm{SE} 130^{\circ} \sim \mathrm{NW} 310^{\circ}$ 附近为主, 充分说明伸展构造的形 成是在同一应力场中完成的.

（2）几何学上的不对称性. 就单个伸展构造而言, 以不对称型式为主体，充分反映了单剪作用的重要 意义. 无论变质核杂岩的上叠盆地还是伸展断陷盆 地常常是一些箕状断陷盆地, 受边缘铲状断裂控制. 从区域组合型式考虑，伸展构造的共轭式或对称式 表现较为明显. 辽南变质核杂岩与万福变质核杂岩 构成一个变质核杂岩对, 而且辽南变质核杂岩和大 营子拆离断层系具有倾向西的拆离断层，断层下盘 向 SEE 方向运动, 但万福变质核杂岩却具有倾向东 的拆离断层，断层下盘向着 NWW 方向运动. 

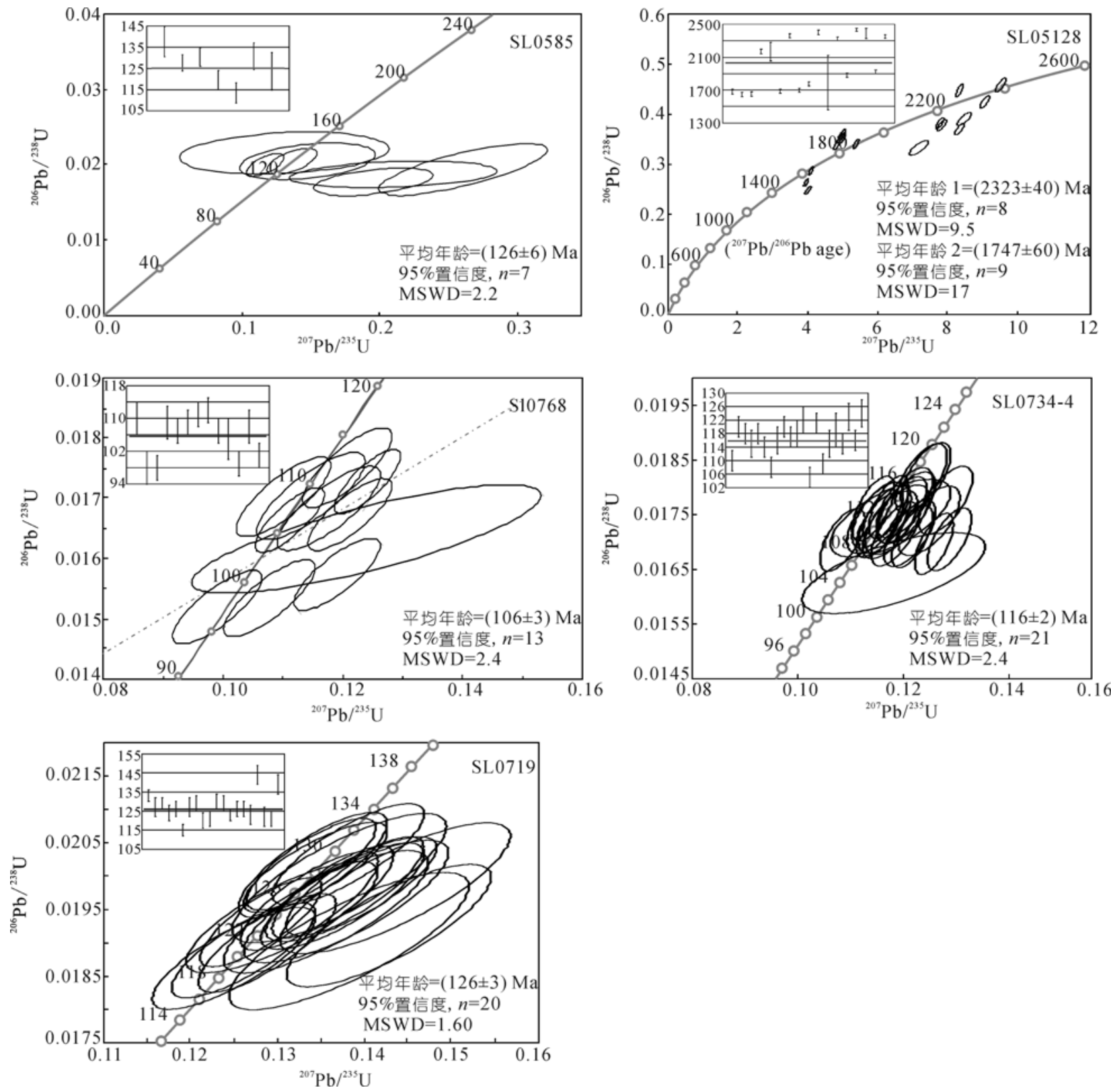

图 10 辽东半岛伸展盆地岩浆岩锆石 U-Pb 年龄谐和线图

（3）强烈的构造-岩浆活动性是区域伸展构造发 育的重要特点, 辽东半岛地区的早白普世大规模岩 浆活动性 ${ }^{[19]}$ 主要表现为区域性花岗质岩石的侵入活 动性. 与此同时, 在变质核杂岩与拆离断层的上叠盆 地或伸展断陷盆地内普遍发育了中酸性(局部基性) 的火山活动性. 后者直接受断陷盆地控制, 具有与伸 展断陷一致的时间和空间关系, 并为伸展断陷活动 提供了重要的时间与深部过程约束.

\section{2 辽东半岛地区伸展构造不均匀性}

（1）伸展构造的分布. 具有分带性，显示地壳切 割深度与伸展量的不均匀性. 总体上西部地区以变 质核杂岩的发育为典型特征，中东部地区发育了拆 离断层构造, 而东部地区则主要表现为断陷盆地的 发育.

（2）形成时间的差异性与跨越性. 辽东半岛地区 的伸展构造组合总体形成于(135 106) Ma，具有宏观 
等时性, 但是不同地区伸展断陷作用及相伴的岩浆 活动性却又有着一定的差异性. 对于伸展盆地火山 岩锆石年代学的测定表明, 其中辽南-万福变质核杂 岩对的剥露时间为 130 113 $\mathrm{Ma}^{[11]}$, 本溪断陷盆地流 纹岩年龄约为 $126 \mathrm{Ma}$, 通远堡长英质岩脉年龄约为 $116 \mathrm{Ma}$, 丹东断陷盆地英安岩年龄约为 $106 \mathrm{Ma}$, 大 营子拆离断层上叠盆地安山岩年龄约为 $132 \mathrm{Ma}$.

(3) 断层产状与切割深度. 辽东半岛地区地壳伸 展与拆离深度的差异性, 很重要的一点为不同地区 伸展断层切割深度的差异, 表现在不同类型伸展构 造的发育及其下盘岩石的变质程度差异. 伸展断陷 盆地(通远堡、本溪和丹东)受高角度正断层控制, 仅 仅发育于浅部层次, 断层切割深度小于 $5 \mathrm{~km}$, 下盘 未剥露出变质岩石; 拆离断层(大营子)切过变质基底 岩石, 往往是一些低角度正断层或正断层组合, 下盘 可以剥露出高达低角闪岩相变质岩石; 变质核杂岩 (辽南-万福)的主拆离断层切割深度大, 可以剥露出 变质级别达到高角闪岩相的变质岩石.

\section{3 区域变化}

早白严世的伸展构造组合在中国东部甚至欧亚 大陆东部(从贝加尔向南经过蒙古北部, 到中国的东 北和华北地区)广泛分布, 并表现出显著的分带性和 宏观统一性 ${ }^{[20 \sim 22]}$ (图 11).

在华北克拉通区与贝加尔湖畔, 以发育变质核 杂岩为主, 局部有孤立发育的半地堑盆地 ${ }^{[23]}$. 在华北 克拉通区, 北缘发育了亚干与呼和浩特变质核杂岩, 南缘出现小秦岭变质核杂岩及大别山伸展构造 ${ }^{[24]}$, 在内陆地区发育了包括云蒙山变质核杂岩、医巫问山 变质核杂岩和辽南变质核杂岩等在内的一系列变质 核杂岩构造 ${ }^{[3]}$. 鉴于华北克拉通主体上被渤海湾盆地 与鄂尔多斯盆地所覆盖, 难以揭示其深部白严纪伸 展构造的发育状况, 从地表出露的变质核杂岩的发 育情况, 可以认为它们在华北克拉通区普遍存在, 又 表现出显著的不均匀性. 在贝加尔-蒙古北部地区的 Khilok 带, 发育了十几个变质核杂岩构造 ${ }^{[21,25]}$. Buteel 变质核杂岩与 Zagan 变质核杂岩侧向相连 ${ }^{[26]}$, 总体上 NE-SW 向延伸, 下盘均由正片麻岩、面理化糜棱岩化的花岗质岩石及矽线石片麻岩、石英岩和斜 长角闪岩等角闪岩相变质岩石组成, 其中的正长岩 与碱性花岗岩给出侏罗纪年龄. 片麻岩系向上逐渐 转变为主拆离断层带糜棱岩系岩石. 上盘岩石由未
变质脆性变形的二叠纪与三叠纪火山-沉积岩组成, 并被同时代的花岗质岩体侵入. Buteel 变质核杂岩上 叠盆地中发育了陆相碎屑岩与玄武岩建造, 其中的 沉积岩中含有早白严世化石组合, 而玄武岩具有 143 130 Ma 的 K-Ar 年龄 ${ }^{[27]}$; 同时, Zagan 变质核杂岩 拆离断层带上同构造新生矿物角闪石与黑云母的 $\mathrm{K}-\mathrm{Ar}$ 年龄分别为 $(127 \pm 2)$ 和 $112 \mathrm{Ma}$. 另外, 两个变质 核杂岩的主拆离断层带上保留了一致的剪切指向标 志, 指示出下盘向 NW 方向运动的特点.

蒙古东部和南部、内蒙古银根-额济纳旗和大兴 安岭-松辽盆地一线, 主要发育了大型半地堑盆地群 (图 11). 东蒙古地区发育了 40 余个断陷盆地, 松辽地 区发育了包括松辽断陷盆地(徐家围子断陷)及其外 围盆地群(包括大杨树盆地、拉布达林盆地、根河盆

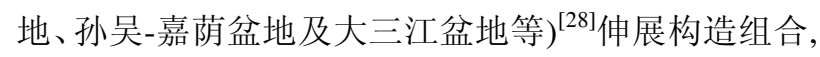
局部发育变质核杂岩构造(即松辽变质核杂岩 ${ }^{[29]}$ ). 区 域上盆地及控盆断裂总体以 NNE 向展布为特征, 拆 离断层下盘位移方向显示出 NWW-SEE 方向的区域 性伸展作用. 松辽变质核杂岩以一条巨大的低角度 拆离断层将上覆古生界浅变质沉积岩系和白严系断 陷盆地与下伏深变质岩系分隔开来 ${ }^{[29]}$. 拆离断层带 为一厚度变化不等的构造岩带, 钻井资料揭示出包 括了较浅部的糜棱岩和深部的糜棱片麻岩. 下盘岩 石由太古宙到侏罗纪(同位素年龄依次为: 2793, 305, 287 和 $165 \mathrm{Ma}$ )的变质岩和侵入岩构成, 包括片岩和 片麻岩(变辉长岩、斜长角闪岩、变流纹质凝灰岩、 绢云片岩、绿泥片岩和黑云母阳起石石英片岩等 $)^{[30]}$, 并被二长花岗岩、花岗岩和闪长岩所侵入. 拆离断层 带上盘的松辽断陷盆地与外围各个断陷盆地普遍具 有相似的盆地充填序列, 下部为面型火山岩-裂陷沉 积序列, 中部坳陷沉积序列, 上部反转沉积序列和顶 部断坳沉积序列.

伸展构造与地壳拆离作用具有运动学极性 (NWW-SEE)、几何学对称与不对称性、遍布全区但 不均匀性以及形成时间的渐进与跨越性 (主体为 130 110 Ma)等特点, 它们为探讨区域岩石圈伸展与 破坏方式提供了重要的约束 ${ }^{[3]}$. 图 11 示华北到贝加 尔湖畔整个东亚地区白严纪伸展构造的发育, 显现 出 4 个构造域: I 和III强烈伸展构造域发育大量的变 质核杂岩构造, 而 II 和 IV 弱伸展构造域以发育拆离 断层及断陷盆地占主导地位, 局部发育有变质核杂 岩构造(如松辽变质核杂岩 ${ }^{[29]}$ ). 分带性在辽东半岛地 


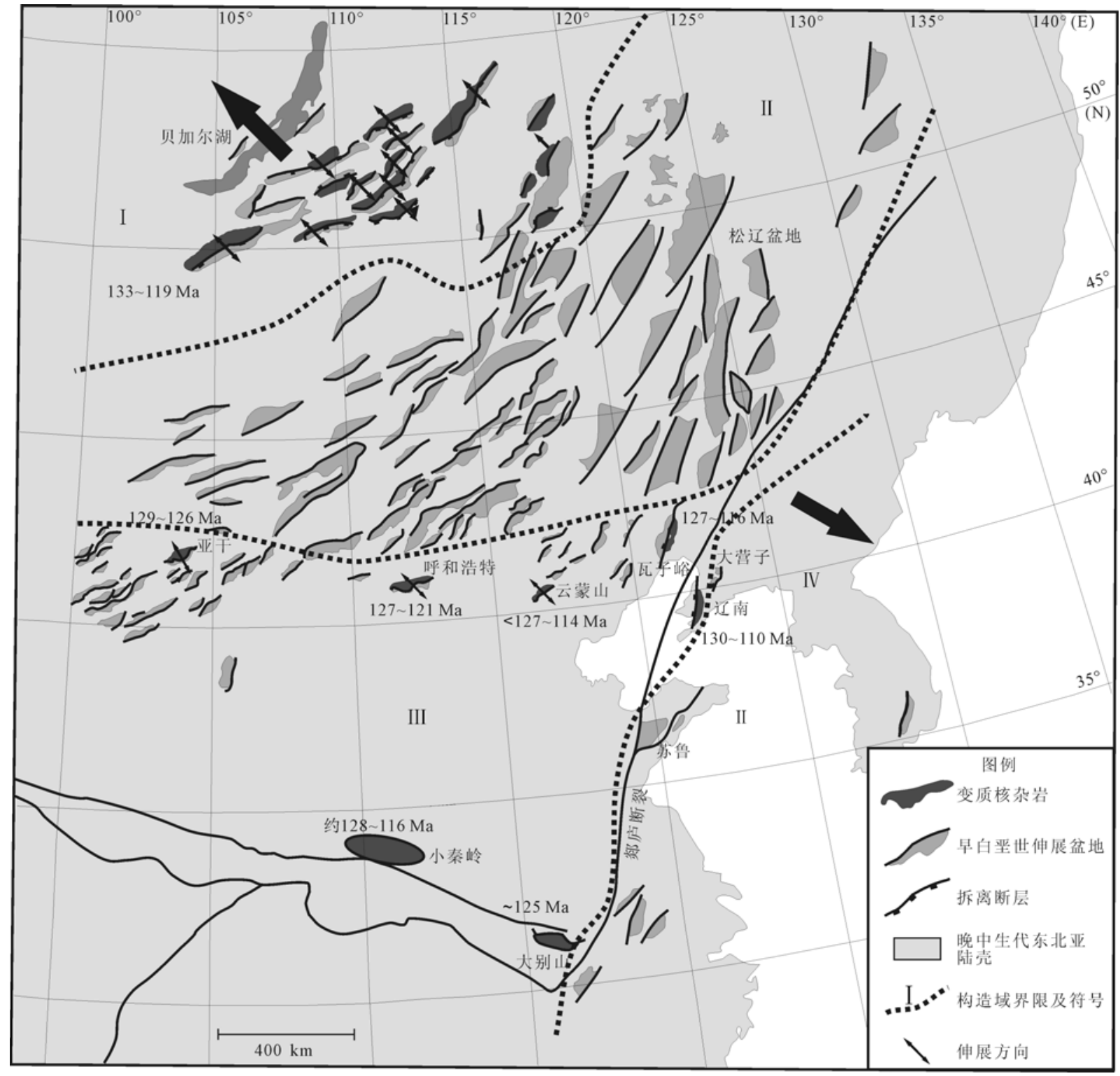

图 11 东亚地区伸展构造组合分带性 ${ }^{[20 ~ 22,25]}$

I 和III, 变质核杂岩构造域; II, 断陷盆地构造域; IV, 拆离断层构造域

区有明显的体现, 西部地区以变质核杂岩为典型, 向 东依次出现拆离断层和断陷盆地. 无论是辽东半岛 还是东亚地区, 岩石圈破坏和减薄的不均一性与分 带性都显而易见.

\section{4 华北克拉通晚中生代岩石圈伸展与减薄机制 讨论}

早白严世华北克拉通乃至东亚地区伸展构造广 泛发育并具有共性与统一性. 它们具有运动学极性、
几何不对称性、形成时间近等时性与跨越性、遍布但 分布不均匀性和规模上具有级序性等 ${ }^{[6]}$. 具有上述统 一性特点的地壳伸展构造组合发育于相似的深部岩 石圈结构背景环境中, 从辽宁东沟到内蒙古东乌珠 穆沈旗地区穿过不同大地构造单元的 GGT 剖面上岩 石圈厚度的均匀性充分证实了这一点 ${ }^{[31]}$.

东亚岩石圈的区域性 NW-SE 向均匀伸展是华北 克拉通地区乃至东亚地区区域伸展构造发育的动力 学背景环境的解释. 从辽南与万福变质核杂岩的成 
对出现, 以及区域上主拆离断层带的面向规律可以 认为, 伸展作用条件是一个均匀的具有纯剪特点的 应力场. 华北克拉通乃至东亚地区伸展构造的分带 性及其所显示的岩石圈变形特点的差异与壳幔结构 的不均匀性变化密切相关.

基于岩石圈流变性分析和壳幔耦合与解耦规律 建立的岩石圈伸展与壳-幔拆离模型, 对于早白严世 岩石圈减薄与地壳伸展构造的发育给予了合理的解 释 ${ }^{[32]}$. 以女山为代表的华北克拉通东部地区在晚中 生代伸展作用过程中壳-幔具有典型的解耦性, 上部 地壳、下部地壳和岩石圈地幔的变形具有显著差异性. 中上地壳与地幔发生拆离作用, 而下部地壳上部则 以塑性流动变形占主导. 地壳拆离作用在浅部层次 形成大量的伸展拆离构造, 导致下部地壳发生减压 熔融而产生壳源岩浆活动性; 地壳拆离作用与地幔 拆离作用共同引起岩石圈地幔内部的减压熔融, 并 诱发软流圈地幔的局部上涌. 介于壳-幔之间或下地 壳上部与下地壳下部之间存在一个滑移带, 也即壳幔解耦带. 它们的存在一方面导致壳-幔之间具有显 著的差异性, 另一方面为岩石圈地幔拆离诱发的幔 源岩浆的底侵就位提供了有利空间. 以汉诺坝为代 表的华北克拉通西部地区, 在伸展作用过程中壳幔
呈耦合状. 下部地壳与岩石圈地幔共同构成流变学 强度很高的岩石圈根. 这一地区由于具有较强的岩 石圈根(下地壳+岩石圈地幔), 岩石圈(无论是地壳还 是地幔)将很难发生区域性的拆离作用; 即使发生拆 离作用, 也应主要集中于中上地壳层次.

对于早白严世区域伸展作用的动力来源, 自侏 罗纪以来开始发生西向(NWW 向)俯冲的 Izanagi 板块 与欧亚板块之间的交互作用是最为重要的因素. 以 下两个方面的过程都会引起欧亚板块边缘及东部(可 以延伸到板内上千公里范围)岩石圈遭受强烈的伸展 作用改造.

（1）俯冲角度变化. 大洋岩石圈板块的初始俯冲 作用, 起始于较低角度的俯冲, 这种环境中的大洋板 块与大陆板块之间强烈推挤, 发生强烈的挤压变形. 随着俯冲作用的持续进行, 重力作用将促使俯冲中 的板块下沉, 而使得俯冲角度逐渐增大. 它一方面直 接导致岩石圈遭受一定的伸展作用, 另一个重要的 效应在于使得下伏软流圈受到扰动而出现不平衡的 循环, 也可能为上覆岩石圈板块中伸展应力场的产 生做出一定的贡献(图 12(a)).

(2) Izanagi 板块俯冲回退. 俯冲中的 Izanagi 板块 发生了回退效应, 这一点可以从大兴安岭-松辽地区
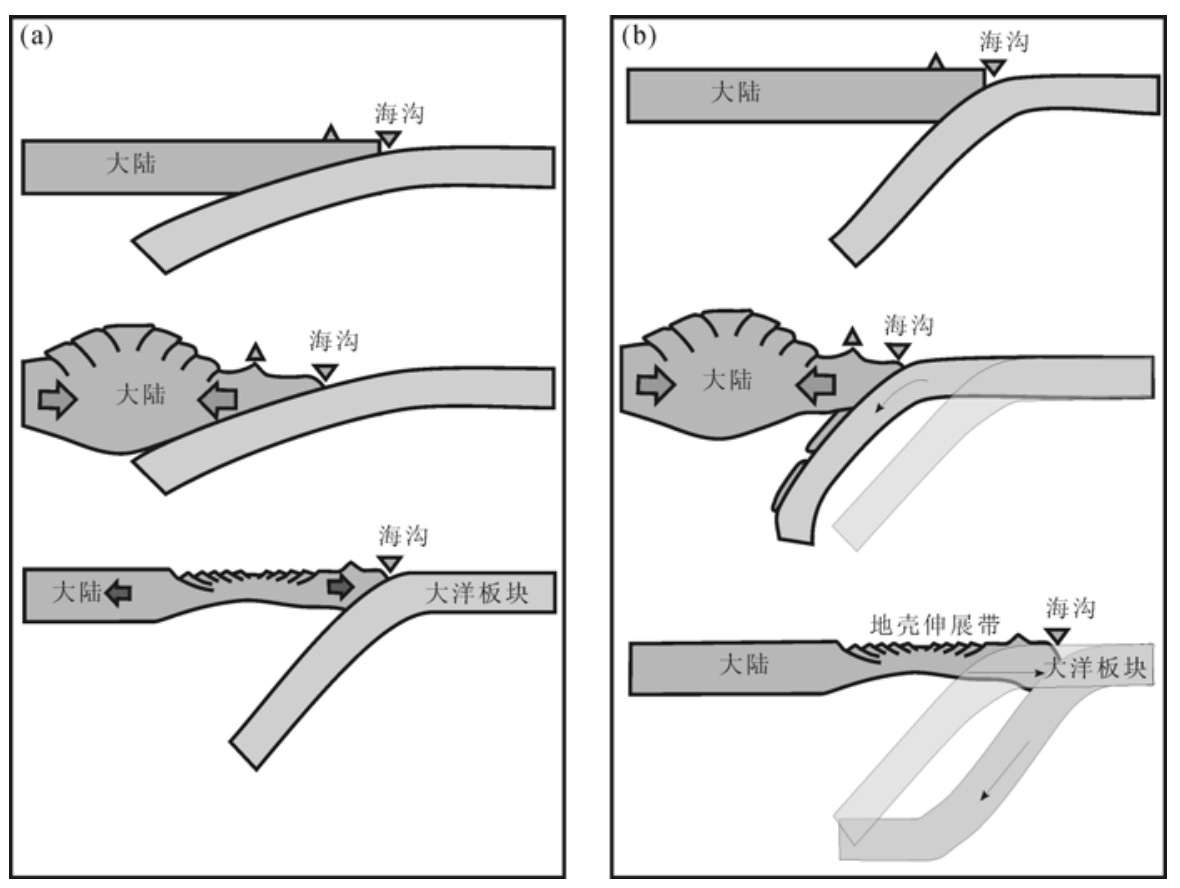

图 12 早白严世 Izanagi 板块俯冲与欧亚板块的响应

(a) 俯冲角度变化; (b) Izanagi 板块俯冲回退 
火山岩时代迁移研究中得到证实 ${ }^{[33]}$, 应用古地磁资 料计算出的 Izanagi-欧亚板块相对运动速度变化得出 了相同的结论. 回退的大洋板块直接影响着欧亚大 陆板块边缘, 并波及其板内, 产生一个区域性 NW-SE 向伸展应力场(图 12(b)).

\section{4 结论}

（1）辽东半岛地区广泛发育有多种不同类型的 伸展构造型式, 主要包括伸展断陷盆地(通远堡、本溪 和丹东)、拆离断层(大营子)和变质核杂岩(辽南和万 福), 它们具有宏观一致性但却表现出一定的差异.
（2）辽东半岛地区伸展构造的发育总体上介于 135 106 Ma 之间，但是各个伸展构造的发育时间有 一定的差异; 伸展构造宏观上构成共轭组合, 但单个 伸展构造却具有不对称性.

（3）华北、东北、华南乃至蒙古和俄罗斯远东地 区的早白严世伸展构造与辽东半岛地区伸展构造的 发育具有统一的组合规律, 可以说辽东半岛地区伸 展构造的发育是东亚早白严世伸展构造域的缩影.

(4) Izanagi 板块与欧亚板块之间的交互作用以及 东亚地区岩石圈结构调整、深部流体活动性和壳幔拆 离作用是制约东亚地区早白严世伸展构造发育的重 要因素.

\section{参考文献}

1 池际尚，路风香. 华北地台金伯利岩及古生代岩石圈地幔特征. 北京: 科学出版社, 1996. 21

2 Yang J H, Wu F Y, Chung S L, et al. Rapid exhumation and cooling of the Liaonan metamorphic core complex: Inferences from ${ }^{40} \mathrm{Ar} /{ }^{39} \mathrm{Ar}$ thermochronology and implications for Late Mesozoic extension in the eastern North China Craton. Geol Soc Am Bull, 2007, 119: $1405-1414$

3 Liu J L, Guan H M, Ji M, et al. Late Mesozoic metamorphic core complexes: New constraints on lithosphere thinning in North China. Prog Nat Sci, 2006, 16: 633-638

4 Liu J L, Davis G A, Ji M, et al. Crustal detachment and destruction of the keel of North China Craton: Constraints from Late Mesozoic extensional structures. Earth Sci Front, 2008, 15: 72-81

5 朱志澄. 构造地质学. 武汉: 中国地质大学出版社, 1990. 164-172

6 Liu J L, Davis G A, Lin Z Y, et al. The Liaonan metamorphic core complex, southeastern Liaoning Province, North China: A likely contribution to Cretaceous rotation of eastern Liaoning, Korea and continuous areas. Tectonophysics, 2005, 407: 65-80

7 关会梅, 刘俊来, 纪沫, 等. 辽宁南部万福变质核杂岩的发现及其区域构造意义. 地学前缘, 2008, 15: 199-208

8 吴福元，杨进辉，柳小明. 辽东半岛中生代花岗质岩浆作用的年代学格架. 高校地质学报, 2005, 11: 305-317

9 Wu F Y, Lin J Q, Wilde S A, et al. Nature and significance of the Early Cretaceous giant igneous event in eastern China. Earth Planet Sci Lett, 2005, 233: 103-119

10 郭春丽, 吴福元, 杨进辉, 等. 中国东部早白严世岩浆作用的伸展构造性质一一辽东半岛南部饮马湾山岩体为例. 岩石学报, 2004 , 20: $1193-1204$

11 纪沫, 刘俊来, 胡玲, 等. 辽南变质核杂岩饮马湾山和赵房岩体铅石 SHRIMP U-Pb 年龄及其地质意义. 地质学报, 2009, 25: 173-181

12 申亮，刘俊来，胡玲，等. 辽东半岛大营子拆离断层系及其区域构造意义. 中国科学：地球科学, 2011, 41: 437一 451

13 Compston W, Williams I S, Kirschvink J L, et al. Zircon U-Pb ages for the Early Cambrian time-scale. J Geol Soc, 1992, 149: 171-148

14 Williams I S. U-Th-Pb geochronology by ion microprobe. In: McKibben M A, Shanks W C III, Ridley W I, eds. Applications of Microanalytical Techniques to Understanding Mineralizing Processes. Rev Econ Geol, 1998, 7: 1-35

15 Xie Y X, Wenk H R, Matthies S. Plagioclase preferred orientation by TOF neutron diffraction and SEM-EBSD. Tectonophysics, 2003, 370 : 269-286

16 Wedenbeck M, Alle P, Corfu F, et al. Three natural zircon standards for U-Th-Pb, Lu-Hf, trace element and REE analysis. Geostand Newslett, 1995, 19: 1-23

17 Jackson S E, Pearson N J, Griffin W L, et al. The application of laser ablation-inductively coupled plasma-mass spectrometry to in situ U-Pb zircon geochronology. Chem Geol, 2004, 211: 47-69

18 Anderson T. Correction of common lead in U-Pb analyses that do not report ${ }^{204} \mathrm{~Pb}$. Chem Geol, 2002, 192: 59-79

19 Wu F Y, Sun D Y, Li H M, et al. A-type granite in North China: Age and geochemical constrains on their petrogenesis. Chem Geol, 2002, 
187: $143-173$

20 Darby B J, Davis G A, Zhang X H, et al. The newly discovered Waziyu metamorphic core complex, Yiwulü Shan, western Liaoning Province, Northeast China. Earth Sci Front, 2004, 11: 143-155

21 Zorin Y A, Novoselova M R, Turutanov E K H, et al. Structures of the lithosphere of the Mongolia-Siberian Mountainous Province. J Geodyn, 1990, 11: 327-342

22 Lin W, Faure M, Moni P, et al. Mesozoic extensional tectonics in eastern margin of Eurasia Continent, the case study of South Liaodong Peninsula dome, NE China. J Geol, 2008, 116: 134-154

23 朱光, 胡召齐, 陈印, 等. 华北克拉通东部早白严世伸展盆地的发育过程及其对克拉通破坏的指示. 地质通报, 2008, 27: 1594-1604

24 Ratschbacher L, Hacker B R, Calvert A, et al. Tectonics of the Qinling (Central China): Tectonostratigraphy, geochronology, and deformation history. Tectonophysics, 2003, 366: 1-53

25 Zorin Y A. Geodynamics of the western part of the Mongolia-Okhostk collisional belt, Trans-Baikal region (Russia) and Mongolia. Tectonophysics, 1999, 306: 33-56

26 Donskaya T V, Windley B F, Mazukabzov A M, et al. Age and evolution of late Mesozoic metamorphic core complexes in southern Siberia and northern Mongolia. J Geol Soc, 2008, 165: 405-421

27 Ivanov V G, Yarmolyuk V V, Smirnov V N. New data on the age of volcanism evidence in West-Zabaikalian late Mesozoic-Cenozoic volcanic domain. Doklady Earth Sci, 1995, 345: 648-652

28 杨建国, 吴河勇, 刘俊来. 大庆探区外围盆地中、新生代地层对比及四大勘探层系. 地质通报, 2006, 25: 1088-1093

29 张晓东, 余青, 陈发景, 等. 松辽盆地变质核杂岩和伸展断陷的构造特征及成因. 地学前缘, 2000, 7: 411-419

30 裴福萍, 许文良, 杨德彬, 等. 松辽盆地基底变质岩中锆石 U-Pb 年代学及其地质意义. 科学通报, 2006, 51: 2881-2887

31 卢造勋, 夏怀宽. 内蒙古东乌珠穆沁旗至辽宁东沟地学断面. 北京: 地震出版社, 1992

32 刘俊来, 纪沫, 夏浩然, 等. 华北克拉通晚中生代壳-幔拆离作用: 岩石流变学约束. 岩石学报, 2009, 25: 1819-1829

33 Wang P J, Liu W Z, Wang S X, et al. Geochemical and Nd-Sr-Pb isotopic composition of Mesozoic volcanic rocks in the Songliao Basin, NE China. Geochem J, 2006, 40: 149-159 